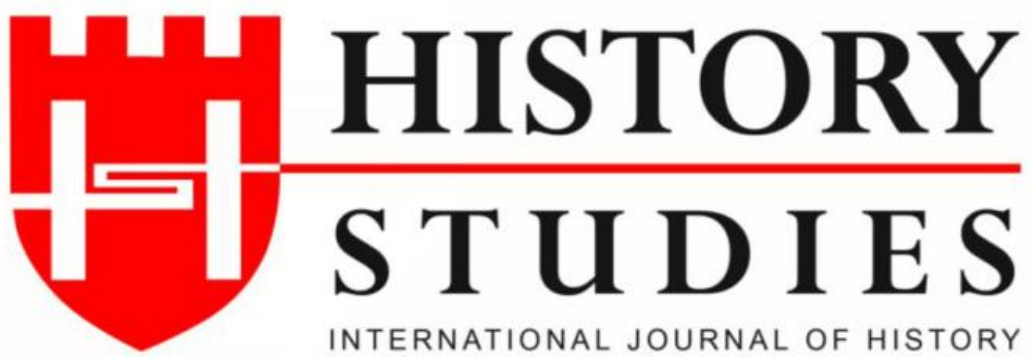

ISSN: 13094173 (Online) 1309 - 4688 (Print)

Volume 12 Issue 2, A Tribute to Assoc. Prof. Dr. İlknur Mangır Karagöz, April 2020 DOI Number: 10.9737/hist.2020.839

Araştırma Makalesi

Makalenin Geliş Tarihi: 07.01.2020 Kabul Tarihi: 07.02.2020

Atıf Künyesi: Irmak Karabulut, “Lozan Antlaşması Sonrası Kurulan Karma Hakem Mahkemeleri: Türk-İngiliz Karma Hakem Mahkemesi ve Üç Örnek Dava”, History Studies, Doç. Dr. İlknur Mangır Karagöz Armağanı, 12/2, Nisan 2020, s. 437-465.

\title{
Lozan Antlaşması Sonrası Kurulan Karma Hakem Mahkemeleri: Türk-İngiliz Karma Hakem Mahkemesi ve Üç Örnek Dava
}

\author{
Dr. Irmak Karabulut \\ ORCID No: 0000-0003-1853-8776 \\ Alanya Alaaddin Keykubat Üniversitesi
}

Mixed Arbitral Tribunals Created After the Treaty of Lausanne: Anglo- Turkish Mixed Arbitral Tribunal and Three Example Cases

Volume 12

Issue 2

A Tribute to

Assoc. Prof.

Dr. Illknur

Mangir

Karagöz,

April

2020

Öz: Karma Hakem Mahkemelerinin kurulmaları ve çalışma usulleri Lozan Antlaşmasına dayanmaktadır. Söz konusu mahkemeler Türk vatandaşları ile müttefik devletlerarasındaki Lozan Antlaşmasının ilgili maddelerinde açıklanan türden anlaşmazlıkları ve müttefik devlet vatandaşları ile Türk devleti arasındaki anlaşmazlıkları çözümlemeyi hedeflemişlerdir. Tarafsız bir başkan ve dava ile ilgili iki üyenin katılımı ile oluşan Karma Hakem Mahkemeleri, Türk-Fransız, Türk-İtalyan, Türkİngiliz, Türk-Belçika, Türk- Romen ve Türk-Yunan Karma Hakem Mahkemesi olmak üzere altı adettir. İçlerinde en çok davaya bakan Mahkemelerden biri de Türk-İngiliz Karma Hakem Mahkemesi olmuştur. Biz de bu çalışmamızda Türk-İngiliz Karma Hakem Mahkemesinde peşi sıra görülen ve siyasi bir boyuta sahip olması ve tanınmış kişileri barındırması nedeniyle basın ve kamuoyunda en çok ilgi çeken üç davayı ele almayı uygun bulduk. Bu davalar, Malta sürgünlerinin, eski Hıdiv Abbas Hilmi Paşa'nın ve II.Abdülhamit'in mirasçılarının Karma Hakem Mahkemesinde açtıkları davalardır. Dava süreçlerini büyük ölçüde dönemin basınından takip ettik. Çalışmamızın başlıca kaynaklarını Türk ve İngiliz gazeteleri oluşturmaktadır. Aynı zamanda Osmanlı ve Cumhuriyet arşivinden ve konuyla ilgili yayınlanmış çalışmalardan ve anılardan da yararlandık.

Anahtar Kelimeler: Lozan Antlaşması, Türk-İngiliz Karma Hakem Mahkemesi, Malta Sürgünleri, Hıdiv Abbas Hilmi Paşa, II.Abdülhamit.

Abstract: The creation and working principles of the Mixed Arbitral Tribunals are based on the Treaty of Lausanne. The said tribunals aim for settling disputes which are stated in the relevant articles of the Treaty of Lausanne between Turkish citizens and allied powers and for settling disputes between allied powers and Turkish state. The Mixed Arbitral Tribunals which consist of a neutral president and two members of the case are six, Turkish-French, Turkish-Italian, Turkish-English, Turkish-Belgian, Turkish-Roman and Turkish-Greek Mixed Arbitral Tribunals. Anglo- Turkish Mixed Arbitral Tribunal became one of the Tribunals which ruled a case at most. And in this study, we have agreed to discuss three cases which were tried subsequently in Anglo- Turkish Mixed Arbitral Tribunal and which drew attention at most in the press and public opinion because of having a political extent and notables. These cases are the cases which were opened by the exiles of Malta, old Khedive Abbas Hilmi Pasha and the inheritors of Abdulhamit II. We followed the processes of the cases majorly from the press in that time. Major resources of our study are Turkish and English journals. However, we have benefited from the Ottoman and Republic archives and the studies and memories which were published about the subject.

Keywords: Treaty of Lausanne, Anglo- Turkish Mixed Arbitral Tribunal, exiles of Malta, Khedive Abbas Hilmi Pasha, Abdulhamit II. 
Lozan Antlaşması Sonrası Kurulan Karma Hakem Mahkemeleri...

\section{Giriş}

Karma Hakem Mahkemesi uygulaması 24 Temmuz 1923 tarihli Lozan Antlaşmasına dayanmaktaydı. Mahkemelerin kuruluş gerekçelerini, çalışma koşullarını ve çalışma kapsamlarını Lozan Antlaşmasının ilgili maddelerini takip ederek öğrenebiliriz. Antlaşmasının 65.maddesine göre Lozan'ın yürürlüğe girdiği tarihte Türk egemenliği altında bulunup kimliği ortaya konulabilecek ve 29 Ekim 1914'te müttefiklerin uyruğu olan kimselere ait mallar, haklar ve çıkarlar hak sahiplerine geri verilecektir. Aynı şekilde 29 Ekim 1914'te müttefiklerin egemenliği ya da koruyuculuğu altındaki ülkelerde ya da Balkan Savaşlarından sonra Osmanlı'dan ayrılan ülkelerde bulunup Türk uyruklarına ait olan mallar, haklar ve çıkarlar hak sahiplerine geri verilecektir.

Lozan Antlaşması uyarınca Osmanlı'dan ayrılmış ülkelerde bulunan ve müttefik devletlerce tasfiye konusu yapılmış ya da başka herhangi olağanüstü tedbirler uygulanmış, Türk uyruklarına ait olan mallar, haklar ve çıkarlar konusunda da bu hüküm uygulanacaktır. Antlaşma gereğince Osmanlı'dan ayrılmış bir ülkede bulunup, Osmanlı Hükümetince uygulanan istisnai bir savaş tedbirine konu olduktan sonra, bu ülkede yetkilerini kullanan bağıtlı yüksek tarafların şimdi elinde bulunan mallardan kimliği ortaya konulabilecek olanlar, yasal sahiplerine geri verilecektir. Bağıtlı devletce tasfiye edilmiş taşınmaz mallar konusunda da aynı işlem yapılacaktır. İstenmiş malların kimin olduğu ya da bunların geri verilişi konusunda ortaya çıkacak her türlü anlaşmazlıklar, Karma Hakem Mahkemesine sunulacaktır.

66.maddeye göre bağıtlı yüksek taraflar maliklere, mallarını, haklarını ve çıkarlarını iade ettireceklerdir. İadeden zarara uğramış bulunabilecek üçüncü kişilerin zararlarını gidermekle, iadeyi yaptıran Hükümet yükümlü olacaktır. $\mathrm{Bu}$ zararın giderilmesi konusunda ortaya çıkabilecek olan anlaşmazlıkların çözümünde genel hukuk mahkemeleri yetkili olacaklardır. Zarar gideriminde bulunması gerekenlere karşı, zarara uğramış kişilerin dava açma hakları olacaktır. Bu amaçla, bağıtlı yüksek taraflarca, düşman mallarına, haklarına ve çıkarlarına ilişkin olarak alınmış bütün kullanım işlemleri ya da başka olağanüstü savaş tedbirleri hemen kaldırılacaktır. İstemde bulunan maliklerin malları, hakları ve çıkarları bunların sahipleri belli olur olmaz derhal geri verilerektir.

Geri verilmesi altmış beşinci maddede öngörülen mallar, haklar ve çıkarlar, işbu antlaşmanın imza tarihinde bağıtlı yüksek taraflardan birinin yetkili makamlarınca tasfiye edilmiş bulunursa, bu bağıtlı taraf, tasfiye tutarını, malların, hakların ve çıkarların maliklerine ödeyerek, geri verme yükümünden kurtulmuş olacaktır. Malikin başvurması üzerine, Karma Hakem Mahkemesi, tasfiyenin adil bir değeri tutturacak koşullar altında yapılmamış olduğuna hüküm verirse tasfiyeden elde edilen geliri, adil bir ölçüde arttırabilecektir. Söz konusu mallar, haklar ve çıkarlar, malikleriyle yapılmış anlaşmadan ya da Karma Hakem Mahkemesinin kararından sonra iki ay içinde ödeme yapılmamışsa, geri verilecektir.

70.maddeye göre Lozan'ın yürürlüğe konuluşundan başlayarak yetkili makamlara altı ay içinde ve anlaşmaya varılamazsa Karma Hakem Mahkemesine on sekiz ay içinde yukarıda belirtilen taleplerin sunulmuş olması gerekmektedir.

75.maddeye göre, imtiyaz sözleşmeleri hariç, sonradan düşman durumuna gelmiş taraflar arasında savaştan önce yapılmış olan sözleşmeler bu tarihten itibaren sona ermiş sayılacaktı. Bununla birlikte sözleşmenin taraflarından biri sözleşmenin yapıldığı tarihte yürürlükte tutulması istenilen koşullar arasındaki farkı karşılayacak bir tazminat ödemesi durumunda Lozan'1n yürürlüğe koyuluşundan en geç üç ay içerisinde karşı taraftan bu sözleşmenin uygulanmasını isteyebilir. Tazminat meselesinde taraflar kendi aralarında anlaşamazlarsa konu Karma Hakem Mahkemesine gidecektir. 
77.maddeye göre, 30 Ekim 1918'den sonra müttefiklerle Türk uyrukları arasında yapılan sözleşmeler ve bu tarihten 16 Mart 1920'ye kadar İstanbul Hükümeti ile usulüne uygun yapılan sözleşmeler geçerlidir. 16 Mart 1920'den sonra İstanbul Hükümetiyle usulüne uygun olarak yapılmış olan ve Hükümetin yönetimindeki topraklara ilişkin tüm sözleşmeler ve anlaşmalar, Lozan'ın yürürlüğe girişinden başlayarak üç ay içerisinde TBMM'nin onayına sunulacaktır. Sözleşmeler uygun bulunmazsa tarafların tazminat hakkı doğacak ve anlaşma sağlanamadığı durumda tazminat Karma Hakem Mahkemesinde saptanacaktır.

78.maddeye göre, sonradan düşman olmuş taraflar arasında imtiyaz sözleşmeleri dışındaki sözleşmelere ilişkin ortaya çıan ve mahkemeye başvuru tarihi olan altı aylık sürenin bitiminden önce ortaya çıkabilecek her türlü anlaşmazlık Karma Hakem Mahkemesinde çözülecektir. Bu maddenin hükümleri, savaş boyunca aynı ülkede oturmuş ve hem kendileri hem de malları bakımından hareket özgürlüğü olan taraflar arasında yapılmış görüşmelerde, tarafların düşman oldukları tarihten önceki yetkili bir mahkemece hükme bağlanmış anlaşmazlıklara uygulanamaz.

81.maddeye göre borcun güvencesi olarak savaş öncesi kabul edilmiş ipotekli bir taşınmaz malın ya da bir rehinin paraya çevrilmesi için savaştan önce yapılan satış geçerli sayılacaktır. Borçlunun zarar ve ziyanı konusunda hesaplaşmak üzere alacaklıyı Karma Hakem Mahkemesine çağırması hakkı saklı tutulacaktır. Mahkeme, tarafların hesaplarını tasfiye etmek, güvence olarak verilen malın satış şartlarını incelemek ve alacaklıyı, borçlunun satış yüzünden uğramış olabileceği zararı onarmaya yükümlü tutmakla görevlidir. Bu hüküm, sadece düşmanlar arasında uygulanabilecek ve 1 Mayıs 1923 tarihinden sonra yapılmış olanlara uygulanmayacaktır.

89.maddeye göre müttefik devlet uyrukları ile Osmanlı uyrukları arasında savaştan önce

Volume 12

Issue 2

A Tribute

to Assoc.

Prof. Dr.

İlknur

Mangir

Karagöz,

April

2020 yapılmış işletme lisansları ya da edebiyat-sanat yapıtlarının çoğaltılmasına ilişkin sözleşmeler Türkiye ile müttefikler arasında savaşın başlaması ile sona ermiş sayılır. Bununla birlikte daha önce bu çeşit bir sözleşmeden yararlananlar Lozan'ın yürürlüğe girişinden başlayarak altı ay içerisinde hak sahibinden yeni bir lisans isteyebilecektir. Taraflar arasında anlaşma olmazsa konu Karma Hakem Mahkemesine gidecekti.

137.maddeye göre 30 Ekim 1918'den Lozan'ın yürürlüğe girişine kadarki sürede İstanbul'u işgal eden devletlerce kendi uyruklarıyla yabancıların ya da Türk uyruklarının malları, hakları ve çıkarları ile bu kimselerin Türkiye makamlarıyla ilişkileri konusunda verilmiş kararlar ya da emirler geçerli sayılacak ve bu kararlarla buyruklar yüzünden, bu devletlere ya da onların makamlarına karşı hiç bir istemde bulunulamayacaktır. Bu kararlar ve emirler yüzünden uğranılan bir zarardan doğan bütün öteki istemler, Karma Hakem Mahkemesine sunulacaktır.

138.maddeye göre bir askeri mahkeme ya da bir polis mahkemesince verilmiş bir hüküm nedeniyle kişinin uğradığı bir zararın onarılmasını talep etmesi durumunda konu Karma Hakem Mahkemesine götürülecek ve mahkeme tazminatta bulunulmasını, eski durumuna getirilmesini zorunlu kılabilecektir. ${ }^{1}$

Lozan Antlaşmanın III. Bölüm V. Kesiminde "Hakemlik Karma Mahkemesi” başlığı altında yer alan 92 ile 98 maddeler Karma Hakem Mahkemelerinin çalışmalarını düzenlenmekteydi. 92.maddeye göre müttefik devletlerle Türkiye arasında Lozan'ın yürürlüğe girişinden başlayarak üç ay içerisinde Karma Hakem Mahkemeleri kurulacaktır. Bu mahkemelerden her biri, ikisi ilgili hükümetçe atanmak üzere, üç üyeden oluşacaktır. Mahkeme başkanı, ilgili iki

\footnotetext{
${ }^{1}$ Seha Meray, Lozan Barış Konferansı Tutanaklar-Belgeler, Konferansda İmzalanan Senetler (30 Ocak ve 24 Temmuz 1923), İkinci Takım, C. II, Yapı Kredi Yayınları, İstanbul, 2001, s. 22-28, 33,47.
} 
hükümet arasında anlaşma ile seçilecektir. İşbu antlaşmanın yürürlüğe girişi tarihinden başlayarak iki aylık bir süre içinde anlaşmaya varılamazsa, söz konusu başkan, ilgili hükümetlerden birinin talebi üzerine, La Haye Adalet Divanı Başkanınca, savaş sırasında tarafsız kalmış devletlerin uyrukları arasından seçilecektir.

93.maddeye göre Karma Hakem Mahkemesinin toplanma yeri İstanbul'dur. Her hükümet, mahkemede kendisini temsil ettirmek için, bir ya da birkaç ajan atayacaktır. Karma Hakem Mahkemesi kuruluşundan itibaren üç yıl sonra çalışmasını tamamlayamadığı durumda başka bir ülkeye taşınabilecektir.

94.maddeye göre Karma Hakem Mahkemelerinde kararlar oyçokluğuyla alınacaktır. Bağıtlı yüksek taraflar, Karma Hakem Mahkemelerinin kararlarını kesin saydıklarını ve kendi uyruklarına bunlara uyulmasını zorunlu kılacaklarını ve mahkeme kararları kendilerine bildirilir bildirilmez, hiçbir yürütme kararı beklemeksizin, ülkelerinde bunların uygulanmasını sağlayacaklarını kabul etmişlerdir.

95.maddeye göre her mahkeme, kullanacağı dili saptayacaktır. Bu maddede yargılama usulü hakkında ayrıntılı bilgi verilmiştir. Tarafların karş1lıklı tezlerini bildirmesi önemsenmiştir. Mahkemenin kuruluşundan itibaren geçen altı aydan sonra, hiç bir başvuru kabul olmayacaktır. Mahkeme tatil dönemleri hariç davanın çabuk görülmesi için her hafta gerekli sayıda oturum yapmakla görevli olacaktır. Dava duruşmasının bitimi tarihinden sonra en fazla iki ay içinde, hüküm verilmelidir. Hüküm açık oturumda bildirilecektir.

96.maddeye göre hükümetler, her mahkeme için sekreter ve genel sekreter atayacaklardır.

97.maddeye göre her hükümet, Karma Hakem Mahkemesine atadığı üyenin, her ajanın ve sekreterin ödeneğini kendisi karşılayacaktır. Mahkeme başkanıyla genel sekreterin ödenekleri, ilgili hükümetler arasında anlaşmayla saptanacak ve bu ödenekler ile mahkemeye ilişkin giderler, ilgili hükümetlerce yarı yarıya karşılanacaktır.

98.maddeye göre Karma Hakem Mahkemesi uygulaması Türkiye ile Japonya arasındaki anlaşmazlıkları kapsamamaktadır. ${ }^{2}$

Kısa bir süre sonra uygulamaya geçildi ve önce beş adet Karma Hakem Mahkemesi kuruldu. Aralık 1924'te Karma Hakem Mahkemelerine delegeler tayin edilmeye başlandı. İstanbul Üniversitesi Hukuk profesörü Cemil Bey Türk-Romen ve Türk-Yunan Karma Hakem Mahkemesine; Ceza hukuku profesörü Tahir Bey Türk-İngiliz ve Türk-İtalyan Karma Hakem Mahkemesine; Temyiz mahkemesi eski başkanı Osman Bey Türk-Fransız Karma Hakem Mahkemesine delege olarak tayin edildi. ${ }^{3}$

İlerleyen günlerde Karma Hakem Mahkemesi azaları pek çok kez değişti. Cemil Bey Türİngiliz Karma Hakem Mahkemesi azalığına tayin edildi. Kasım 1926'da Türk-İngiliz ve Türkİtalyan Karma Hakem Mahkemesi üyesi Cemil Bey ile Belçika Karma Hakem Mahkemesi üyesi Memduh Beyin görev yerleri karşılıklı olarak değiştirildi. ${ }^{4}$

Çalışmamızın konusunu oluşturan Türk-İngiliz Karma Hakem Mahkemesi başkanlığına senelik 2.500 İngiliz lirası verilmek üzere, La Haye Adalet Divanı Başkanlığınca Danimarkalı Mösyö Hammerich seçilmiştir. Hammerich aynı zamanda Türk-İtalyan Karma Hakem Mahkemesinin de başkanı olmuştur. Hammerich'e ait geliş gidiş masraflarının mevzu bahis üç

${ }^{2}$ Age, s. 33-36.

${ }^{3}$ BOA (Devlet Arşivleri Başkanlığı Osmanlı Arşivi), Hariciye Nezareti İstanbul Murahhaslı̆̆ ( HR. IM.), 246/163, 31.12.1924.

${ }^{4}$ BCA (Devlet Arşivleri Başkanlığı Cumhuriyet Arşivi), Başbakanlık Kararlar Daire Başkanlı̆̆ (1920-1928), 30.18.1.1./ 21.72.13., 24.11.1926.

\section{History Studies}


hükümet arasında paylaştırılması kararlaştırılmıştır. Bakanlar Kurulu da 3 Mayıs 1925 tarihli toplantısında Hammerih'in memuriyetini uygun görmüş ve Hammerih'in Türkiye'nin payına düşen yıllık masrafının Maliye Bakanlığı bütçesinin olağan üstü giderler kısmından ödenmesini kararlaştırmıştır. $^{5}$

$\mathrm{Bu}$ şekilde Lozan'ın ilgili maddeleri gereğince kurulan Türk-İngiliz Karma Hakem Mahkemeleri ancak 1925 Haziran'ında İstanbul'da çalışmalarına başladı. ${ }^{6}$ Karma Hakem Mahkemelerinin kurulmaları ve çalışmalarını tamamlamaları Lozan'da belirtildiği şekilde olmamıştı. Türk-İngiliz Karma Hakem Mahkemesinin çalışma kurallarının belirlenmesi 29 Aralık 1925'te tamamlanırken ilk oturum ancak 22 Şubat 1927 tarihinde yapılmıştır. Mahkemelerin çalışmalarını sona erdirmesi de Lozan'da ön görüldüğü sürede olmamıştı. ${ }^{7}$

Biz bu çalışmamızda Türk-İngiliz Karma Hakem Mahkemesinde görülen 558 davadan basında ve kamuoyunda en çok ses getiren üç önemli davayı ele almayı uygun bulduk; Malta sürgünlerinin davası, Eski Mısır Hıdivi Abbas Hilmi Paşanın davası ve II.Abdülhamit'in mirasçılarının davası.

\section{Malta Sürgünleri Davası}

Mondros Mütarekesinin imzalanması ardından Osmanlı'nın yönetimi, işgal kuvvetleri yüksek komiserlerinin eline geçmişti. İngiliz Hükümeti ilk aşamada savaş suçlusu olarak gördügü kişilerin yakalanmasını İstanbul'daki İngiliz Yüksek Komiseri Amiral Calthorpe'a Şubat 1919 'da bildirmişti. "Savaş suçlusundan" kast edilen mütareke hükümlerine riayet etmeyerek silah birakmayanlar; İngiliz subaylara hakaret edenler; tutsaklara, Ermenilere ve diğer azınlıklara kötü davrananlar; savaş hukukunu çiğneyenlerdi. Tutuklananlar önce Arapyan Hanı ve Bekirağa Bölüğü adı verilen tutukevine gönderildiler, sayılarının artması ardından

Volume 12

Issue 2

A Tribute

to Assoc.

Prof. Dr.

Ilknur

Mangir

Karagöz,

Malta adasına sürüldüler. İngiltere bu şekilde "Türk savaş suçlularının" listesini hazırlarken ABD ve Fransa da kendi listelerini hazırladılar. Bu şekilde rakam gittikçe arttı. Malta'ya bir diğer toplu sürgün Meclis-i Mebusan'ın 28 Ocak 1920 tarihinde Misank-1 Milliyi kabul etmesinin ardından gerçekleşti. ${ }^{8}$

Yaklaşı 144 kişi Mart 1919'da başlayan ve 20 Kasım 1920'de son bulan yirmi aylık süre içerisinde çeşitli sevkiyatlarla gruplar şeklinde Malta adasına sürülmüştür. ${ }^{9}$ İlk sürgün edilenler genellikle cephedeki eski komutanlardan ve ittihatçlardan oluşmuştur. Kısa bir süre sonra İngiltere açısından yeni bir suçlu tipi oluşmuştur: Kemalistler. İstanbul'un işgali ve Meclisin dağıtılması sonrası sürülenler genellikle Kemalistlerdir. ${ }^{10}$ Türkiye'nin asker-sivil ileri gelen isimleri Malta' ya sürgün edilmişlerdi. Aralarında sadrazamlık, şeyhülislamlık, bakanlık, meclis başkanlığı, vekillik, valilik yapmış devlet adamları; genelkurmay başkanlığı, harbiye nazırlığı, ordu komutanlığı yapmış üst düzey askerler; profesörler, gazeteciler, yazarlar vardı. ${ }^{11}$

Mütareke sırasında İngilizler tarafından Malta'ya gönderilenlerin büyük bir kısmı 1926 y1lına gelindiğinde Türk-İngiliz Karma Hakem Mahkemesine başvurarak İngiliz Hükümeti aleyhine dava açmışlardır. Basında bu şekilde ilk ismi geçenler Doktor Esad ${ }^{12}$ ve Çürüksulu

${ }^{5}$ BCA. 30.18.1.1./13.27.11., 3.5.1925.

6 "Telegrams in Brief", The Times, 12 Haziran 1925.

${ }^{7}$ Taner Akçam -Ümit Kurt, Kanunların Ruhu, İletişim Yayınları, İstanbul, 2012, s. 135-136, 173.

${ }^{8}$ Bilal Şimşir, Malta Sürgünleri, Milliyet Yayınları Tarih Dizisi, İstanbul, 1976, s. 42-43, 85-86, 216; Yalçın Toker, Malta Sürgünleri'nden Portreler, Toker Yayınları, İstanbul, 2006, s. 12-14,

${ }^{9}$ Şimşir, age, s. 226; Toker, age, s. 81.

${ }^{10}$ Şimşir, age, s. 136,192 .

${ }^{11}$ Age, s. 11.

${ }^{12}$ Mehmet Esat Işık göz doktorudur. I. Dünya Savaşı sürecince Kızılay Cemiyeti başkanlığı yapmıştır. Paris Tıp Fakültesini bitirmiş, Askeri Tıbbiye 'de hocalık yapmıştır. I. Dünya Savaşı sırasında Sağlık Genel Müdürlüğü 
Mahmud olmuştur. ${ }^{13}$ İlerleyen günlerde bu iki ismin yanına Halk Fırkası Müfettişi Doktor Fazıl Berki $^{14}$, Süleyman Nazif ${ }^{15}$ beyler de eklenmiştir. Bu isimler tarafından dava açılması konusunda mahkemeye dilekçeler verilmiştir. Davacılar, Malta'da sebepsiz olarak tutuldukları gerekçesiyle İngiliz Hükümetinden tazminat talep etmişlerdir. ${ }^{16}$ Esad Bey İngilizlerden 15.000 İngiliz lirası tazminat istemekteydi. Dava açanlara Meclis İdare Reisliği görevinde bulunmuş Hacı Adil ${ }^{17}$ ve eski Vatan gazetesi başyazarı Ahmet Emin Bey ${ }^{18}$ de katılmıştır. Zarar ve ziyan davası açanlardan Süleyman Nazif Beyin dava dilekçesi basında da ilgi görmüş ve yer almıştır. $^{19}$

Kısa sürede mahkemeye başvuranların sayısı artmıştır. Diş doktoru Atıf ve Emekli Miralay Celal Bey de başvuruda bulunmuştur. Celal Bey, Malta'da iken eski sürgünlere "esaret maaşı" verildiği halde kendisine verilmediği için bu maaşı talep etmiştir. Malta sürgünlerinden Eski Hariciye Nazırı Ahmet Nesimi Bey ${ }^{20}$ de dava açanlar arasındadır. Ahmet Nesimi Bey, İngiliz Hükümeti'nden 15.000 lira tazminat talep etmiştir. Ayrıca Malta'ya giderken bir İngiliz zabiti tarafından kendisinden sebepsizce alınan 100 İngiliz lirasının da iadesini istemiştir. ${ }^{21}$ Aka Gündüz'ün ${ }^{22}$ de ismi Mahkemeye başvuranlar arasında geçmektedir.

Malta sürgünlerinden, davalarının görülmesi için 250'şer lira harç talep edilmiştir. Bu talebe itiraz gecikmemiştir. Bununla birlikte Malta sürgünlerinden birkaçı, istenilen parayı verip davaya girişmişlerdir. $\mathrm{Bu}$ davaların neticesine kadar diğer Malta sürgünlerinin açtıkları

yapmış, general rütbesi almıştır. Milli Mücadeleye destek veren Doktor Esat Bey, Milli Kongre'nin toplanmasında büyük katkı sağlamıştır. 30 Ekim 1921'de Malta'dan kurtulanlar arasındadır. Bkz. Toker, age, s. 183.

13 “Malta Menfileri İngilizleri Dava Ediyor”, Cumhuriyet, 16 Eylül 1926. Çürüksulu Mahmut Paşa, İngilizlerin İstanbul'u işgal edip Meclisi bastığı gün tutuklanmıştır. 22 Mart 1920'de Malta'ya sürgün edilmiş ve 30 Eylül 1921'e kadar burada kalmıştır. Bkz. Age, s. 36-37.

${ }^{14}$ Fazıl Berki Tümtürk, Çankırı Mebusluğu ve İttihat ve Terakki Merkez Komitesi üyeliği yapmıştır. 1919'da tutuklanmış önce Bekirağa Bölüğüne, 28 Mayıs 1919'da da Malta'ya hapsedilmiştir. 30 Ekim 1921'de Malta'dan kurtulmuştur. Bkz. Şimşir, age, s. 76, 123, 453.

${ }^{15}$ Süleyman Nazif 1869 'da Diyarbakır'da doğmuştur. 1892'de memurluk hayatına atılmıştır. 1897'de Avrupa'ya kaçmış, Jön Türklere katılmış ve Meşveret gazetesinde istibdat aleyhine yazılar yazmıştır. Pek çok gazete ve dergide yazlar yazan Süleyman Nazif, Basra, Kastamonu, Trabzon, Musul, Bağdat valiliği görevlerinde bulunmuştur. 22 Mart 1920'de Malta'ya sürgüne gönderilmiş, 1 Kasım 1921'e kadar sürgünde kalmıştır. Bkz. Toker, age, s. 157-159.

16 "Malta Menfileri İngilizleri Dava Ediyorlar", "Muhtelit Türk-İngiliz Mahkemesi Reisi Bugün Şehrimize Geliyor", Cumhuriyet, 26 Eylül 1926.

17 Hacı Adil Bey 1869 Lofça doğumludur. İstanbul Hukuk Mektebinden mezun olmuş, Selanik’te hukuk öğretmenliği yapmıştır. II. Meşrutiyet döneminde Tekirdağ milletvekilliği yapmış, Parti Genel Sekreterliği ve İçişleri Bakanlığ1 yapmıştır. Ardından Edirne Valiliği ve Bursa Milletvekilliği yapmıştır. Ocak 1919'da tutuklanmış ve 28 Mayıs 1919'da Malta'ya sürülmüştür. 30 Mayıs 1921'e kadar sürgünde kalmıştır. Serbest kalmasının ardından Adana ve Bursa valilikleri yapmıştır. İstanbul Üniversitesi Hukuk Fakültesi'nde Medeni Hukuk profesörlüğü yapmış ve 1935 'de vefat etmiştir. Bkz. Toker, age, s. 136-137.

${ }^{18}$ Ahmet Emin Yalman 1888'de Selanik’te doğdu. İstanbul Alman Lisesi ve Colombia Üniversitesi'nde eğitim gördü. Sabah gazetesinde gazeteciliğe başladı. İstanbul Üniversitesi sosyoloji bölümünde profesör olarak görev yapt1. 22 Mart 1920'de beraberindeki on bir kişi ile birlikte Malta'ya sürüldü. 30 Ekim 1921'e kadar sürgünde kaldı. Vatan gazetesinin kurucusu Yalman pek çok gazetecilik ödülü almıştır. Bkz. Age, s. 173-174.

19 "İngilizlerin Aleyhine", "Bilasebep Malta'ya Nefy Edilenler İngilizlerden Ne Kadar Zarar ve Ziyan İstiyorlar", Milliyet, 18 Ekim 1926.

${ }^{20}$ Ahmet Nesimi Soyman Hanya doğumludur. Paris’te siyaset eğitimi almış, İttihat ve Terakki Merkez-i Umumi müdürü olmuş ve İstanbul mebusu seçilmiştir. I. Dünya Savaşı döneminde Ziraat ve Ticaret Bakanlığı, Dışişleri Bakanlığ1 yapmıştır. 28 Mayıs 1919'da Malta'ya sürülmüştür. 30 Mayıs 1921'e kadar sürgünde kalmıştır. 1926 İzmir suikastı davasında yargılanmış ve beraat etmiştir. 1958 yılında ölmüştür. Bkz. Toker, age, s. 42-43.

21 "Muhtelit Hakem Mahkemelerinde", "Malta Menfileri”, Cumhuriyet, 19 Ekim 1926.

${ }^{22}$ Aka Gündüz (Enis Avni) 1886'da Selanik’te doğmuştur. Kuleli Askeri Lisesini bitirmesinin ardından Harp Okuluna girmiştir. Paris'te hukuk ve güzel sanatlar eğitimi görmüştür. 31 Mart olayı sonrası Hareket Ordusu içinde görev almıştır. Gazetecilik yapan Aka Gündüz 31 Mart 1920'de Malta'ya sürülmüş, 30 Ekim 1921'e kadar sürgünde kalmıştır. Sürgünden dönmesinin ardından gazetecilikle uğraşmış, 1931'de Ankara milletvekili olmuştur. 1943'e kadar milletvekilliği yapmıştır. Pek çok roman kaleme almıştır. Bkz. Toker, age, s. 175-176. 
davaların harçları alınmayacak ve dilekçeleri iptal de edilmeyecektir. Davacılar, açılan ve harçları verilen davaların neticesine göre istenilen harçları vererek davalarında ısrar edecekler ya da vazgeçeceklerdir. ${ }^{23}$

Türk basını aralarında önemli ve tanınmış isimlerin yer aldığı Malta sürgünleri davasına büyük ilgi gösterdi. Karma Mahkemedeki Türk ajanı Emin Ali Bey, Vakit gazetesine verdiği röportajda, Malta sürgünlerinin mahkemeye yaptıkları müracaatların mahkemece kabul edilmesini temin ettiğini belirtmiş, olumsuz muamelelere maruz kalan ve ülkenin önde gelen isimlerinin aralarında yer aldığı kişilerin haklarını savunmak adına ajanlığın tüm gücü ile mücadele edeceğini vurgulamıştı. Başvuranlar arasında Süleyman Nazif de bulunmaktaydı; bununla birlikte Süleyman Nazif Bey 1927 senesi başında hayatını kaybetmişti. Bu nedenle Emin Ali Bey, Süleyman Nazif Beyin davasını takip edeceğini de belirtmişti. Süleyman Nazif'in vasileri mahkemeye müracaat etmemişlerdi; bununla birlikte Emin Ali Bey mahkeme başkanlığına başvurarak mahkemece vasilerden davaya devam edilip edilmeyeceklerinin sorulmasını talep edecekti. Olumlu cevap alınırsa davaya devam edilecekti. Emin Ali Bey gerekirse davanın açılması için gerekli harcı mahkemenin tahsisatından temin edeceğini, Malta'da çektiği ıstırabın hakkını takip edeceğini vurgulamıştı. Gerekirse mirasçının şahsi vekâletini de mirasçı onayladığı takdirde Türk ajanlığı kabul edecekti. ${ }^{24}$

Şimşir Malta sürgünlerine ilişkin çalışmasında başta davacılar arasında altı kişinin isminin geçtiğini belirtir. Eczaci Mehmet Bey ${ }^{25}$, Albay Celal Bey, Mahmut Kamil Paşa, Ahmet Emin Bey, Doktor Esat Paşa ve Mustafa Abdülhalik ${ }^{26}$. Yukarıda görüldüğ̈̈ üzere basında bu sayılanların dışında isimler de anılmıştır. Bu şekilde bir örnek olarak, davayı Ahmet Emin Bey açmıştır. $^{27}$

Malta sürgünleri davasında ilk olarak 9 Haziran 1927'de Ahmet Emin Beyin İngiliz

Volume 12

Issue 2

A Tribute

to Assoc.

Prof. Dr.

İlknur

Mangir

Karagöz,

April

2020

Hükümeti aleyhine açtığı 15.000 İngiliz liralık zarar ve manevi tazminat davası görüldü. Mahkemenin konusu yetki meselesiydi. Davanın İngiliz tarafı Karma Mahkemenin bu davaya bakmaya yetkili olmadığ mahkeme salonu dinleyicilerle dolup taşmıştı. Mahkeme salonunda tarafsız mahkeme reisi Hammerich, Türk aza Memduh Bey, İngiliz azası Grimston ${ }^{28}$, Türk ajanı Raşid Bey ve İngiliz ajanı Wells vard1.

Ahmet Emin Beyin ve kırk kadar zatın vekâletini almış bulunan Hukuk Fakültesi Hukuk-1 İdare Müderrisi Muslihiddin Adil Bey (Taylan) mahkemede hazır bulunmuştu. Hammerich sözü önce davacı vekili Adil Beye vermiştir. Adil Bey, İngiliz ajanının yetkisizlik talebine karşı

\footnotetext{
23 “Malta Menfileri”, “Muhtelit Mahkemede İkame-i Dava İçin Bundan Sonra Ne Yapılacak?”, Milliyet, 20 Ocak 1927.

24 "Malta Menfileri”, Vakit, 20 Şubat 1927; "İngilizler Aleyhine”, "Süleyman Nazif Merhumun Veresesi Davaya Devam Edecekler Mi?", Milliyet, 20 Şubat 1927.

${ }^{25}$ Eczacı Mehmet Bey aynı zamanda zengin bir iş adamıdır. Özellikle Doğu illerinde müteahhitlik yapmıştır. Malta'da tutuklu bulunduğu sırada İngilizlere dilekçe yazarak İngilizlerce el koyulan sermayesinden bahsetmiştir. Bkz. Şimşir, age, s. 357-358.

${ }^{26}$ Mustafa Abdülhalik Renda 1881 Yanya doğumludur. Osmanlı döneminde kaymakamlık, mutasarrıflık valilik gibi pek çok idari görevde bulunmuştur. Cumhuriyet döneminde de milletvekilliği, TBMM başkanlı̆̆ı ve çeşitli bakanlıklarda bulunmuştur. 1957 yılında vefat etmiştir. Bkz. TBMM Albümü (1920-2010), Haz: Sema YıldırımBehçet Kemal Zeynel, TBMM Basın ve Halkla İlişkiler Müdürlüğü Yayınları No: 1, Ankara, 2010, s.385. 7 Haziran 1920'de sürgüne gönderilmiş, 30 Ekim 1921'de Malta'dan kurtulmuştu. Bkz. Şimşir, age, s. 223,453.

${ }^{27}$ Age, s. 461.

28 İngiliz Hakem daha sonra Büyük Ada'da kaldığı otelin üst katından kendini atmak suretiyle intihara teşebbüs edecek ve görevinden alınacaktır. Bkz. "Malta Menfileri” Milliyet, 3 Temmuz 1928.
} 
çıkmıştır. İngiliz ajanı iddiasında Lozan'ın 58.maddesini gerekçe göstermekteydi. ${ }^{29}$ 58.madde ile Türkiye ve Yunanistan dışında öteki bağıtlı devletler, 1 Ağustos 1914 tarihi ile Lozan'ın yürürlüğe giriş tarihi arasındaki sürede uğramış oldukları, savaş eylemleri, zoralım, haciz ve el koyma tedbirlerinden doğan kayıp ve zararlardan dolayı her türlü parasal istemde bulunma hakkından karşıllıklı olarak vazgeçmişlerdi. ${ }^{30}$ Adil Bey bu aşamada Ahmet Emin Bey ve arkadaşlarının Malta'ya gönderilmelerinin savaş eylemi kapsamında olup olmadığını sormaktadır. Adil Beye göre sürgün savaş eylemi değildir.

Adil Bey, sürgünün devletler hukukuna aykırı bir hareket olduğunu belirtmiş̧ti. Bu konuda 1899 ve 1908 Lahey mukavelenamelerini ve savaş hukuku nizamnamelerini açıklamıştı. Bu anlaşmayı imzalayan İngiltere, anlaşmadan önce cereyan eden görüşmelerde "tağrib"in yani sürgünün bir savaş eylemi sayılmayacağına dair beyana itiraz etmemişti. Adil Bey, sürgünün aile bağlarını bozan bir hareket olduğundan devletler hukuku kaidelerinin dışında olduğunu belirtmişti.

Muslihiddin Adil Bey'in tezi sürgünün mütareke esnasında gerçekleştiğine dayanmaktadır. $\mathrm{Bu}$ konuda batılı devletler hukuku üstatlarının mütareke ve işgal hakkındaki esaslarını izah etmiş ve bu surette sürgünün bir savaş eylemi sayılamayacağını belirtmiştir. Askeri ya da siyasi zaruretin Malta hadisesini mazur gösteremeyeceğini belirtmiştir. Böyle bir zaruretin kabulünün hukuku baltalayacağını vurgulamıştır. Adil Bey Lozan'ın 58.maddesi bertaraf edildiğinden 137.maddesinin uygulanması yani Karma Hakem Mahkemesinin davaya bakmasının gerektiğini belirtmiş̧tir.

Adil Bey, Malta sürgünleri ile harp esirleri ve sivil tutukluların aynı vaziyette olmadıklarını delillerle açıklamış ve bir saat süren konuşmasının sonunda İngiliz Hükümeti'nin geçerli bir sebebi olmaksızın masum insanları sefalet içinde tutmaya hakkı olmadığını söylemiştir. Adil Bey, antlaşmaların devletlerarasındaki barışı sağladığını; fakat gerçek barışı milletin hislerine dayandırdığını belirtmiştir. Her iki tarafın da adalet hissine sahip olması barışı ebedi kılacaktır. Savaşın ve mütarekenin kötü hatıralarının silinmek istenmesi durumunda Türk-İngiliz dostluğunun tekrar sağlanması için geçmişin zulmünün tamir edilmesini ve bir özür gösterilmesini belirtmiştir.

Adil Beyin ardından İngiliz ajanı Wells söz almış ve Malta sürgünlerinin savaş eylemleri içinde değerlendirileceğini ve bu nedenle anlaşmanın 58.maddesinin uygulanmasının gerekeceğini, mahkemenin bu davaya bakmaya yetkisinin olmadığını belirtmiştir. Ardından Türk ajanı Vasfi Raşid Bey söz almış ve Adil Beyin Türk tezini çok doğru bir biçimde savunduğunu, İngiliz ajanının milli hislerinden uzak bir şekilde meseleyi ele aldığında tezi reddetmesinin mümkün olmadığını belirtmiştir. Vasfi Raşid Bey, davaya konu tezin son derece yerinde olduğunu vurgulamıştır. Davanın kabulünü ve davacılara gerekli özrün gösterilmesini talep etmiştir. Bundan sonra mahkeme davayı görmeye yetkili olup olmadığına karar vermek üzere oturumunu tamamlamıştır. ${ }^{31}$

\footnotetext{
29 “Malta'ya Teb'îd Edilenler Haklarını İstiyor”, "Dün Muhtelit Mahkemede Dava Müdellel Bir Surette Teşrih Edildi: Mahkeme Kararını Sonra Verecek”, Milliyet, 10 Haziran 1927; "Malta Menfilerinin Davasına Başlandı”, "Muhtelit Mahkeme Ahmet Emin Beyin Müracaatını Tedkike Salahiyetdar mıdır değil midir?", Vakit, 10 Haziran 1927. Bazı kaynaklarda Ahmet Emin Yalman'ın açtığı tazminat davasının 5.400 liralık olduğu yer almaktadır. Bkz. Şimşir, age, s. 461; Toker, age, s.174,192.

${ }^{30}$ Meray, age, s.20.

31 “Malta'ya Teb'îd Edilenler Haklarını İstiyor”, "Dün Muhtelit Mahkemede Dava Müdellel Bir Surette Teşrih Edildi: Mahkeme Kararını Sonra Verecek", Milliyet, 10 Haziran 1927; "Malta Menfilerinin Davasına Başlandı", "Muhtelit Mahkeme Ahmet Emin Beyin Müracaatını Tedkike Salahiyetdar mıdır değil midir?", Vakit, 10 Haziran 1927.
} 


\section{Abbas Hilmi Paşa Davası}

Türk ve İngiliz kamuoyunun ilgisini çeken bir diğer dava eski Mısır Hıdivi Abbas Hilmi Paşanın $^{32}$ İngiliz Hükümeti aleyhine açtığı dava idi. Birinci Dünya Savaşı patlak verdiği sırada Hıdiv İstanbul'da bulunuyordu, İstanbul'a gelişinden birkaç gün sonra Misırlı bir öğrenci tarafından suikasta uğramıștı. Bir süre sonra İngiliz Hükümeti, Hıdiv Abbas Hilmi Paşayı "İngiltere'nin düşmanlarına bağlı olduğu” gerekçesi ile Mısır tahtından indirdi. Savaş yıllarını Hıdiv genellikle yurt dişında geçirdi. Abbas Hilmi Paşa hem savaş sürecinde hem de savaş ertesi Türkiye'de çok fazla zaman geçirmişti. Türkiye'de pek çok emlake sahip olan Abbas Hilmi Paşa, İngiltere aleyhine dava açtığı dönemde Çubuklu'da yaşamaktaydı.

Abbas Hilmi Paşanın Hıdivlikten ayrılmasından sonra Mısır'daki malları ve emlakları İngilizler tarafından haczedilmiş ve satılmıştı. Bunun nedenini İngiliz basını alacaklılara ödeme yapmak olarak ortaya koymuştu. Savaş sürecinde de Abbas Hilmi Paşanın finansal durumu ile ilgili pek çok görüşme yapılmıştı. Sonunda Hıdive 589, 865 Osmanlı lirası ödenmişti. Bu miktar tüm borçlar ödendikten sonra emlakin ve malların bakiyesini oluşturan meblağ idi. Abbas Hilmi Paşa ise bundan memnun olmayacaktı. Lozan'ın 65 ve 66.maddeleri uyarınca Karma Hakem Mahkemesine başvurup 2,763,825 İngiliz lirası/2,823,103 Türk lirası talepte bulunmaya hazırlandı. Abbas Hilmi Paşa ilaveten Mısır'daki mal ve mülklerinin elden çıkartılmasında alınabilecek en fazla miktarı elde etmesi için hesap yapılmadığını da belirtmişti. Abbas Hilmi Paşanın başlıca malları, İsmailiyye'deki emlaki; Montazah saray, bahçesi ve adası; Musturud ve Kubbeh'deki emlakları ve pek çok hisseden oluşuyordu.

HISTORY STUDIES

445

Volume 12

Issue 2

A Tribute

to Assoc.

Prof. Dr.

İlknur

Mangir

Karagöz,

April

2020

Mayıs 1926'de Abbas Hilmi Paşanın avukatları harekete geçerek Mahkemeye bir tezkere sundu. İngiliz Hükümeti de karşı tezkere sunarak Türk-İngiliz Karma Mahkemesinin bu davaya bakmaya yetkili olup olmadığını sordu ve uzun tezkerenin sonunda Mahkemeyi davayı redde davet etti.

The Times bu davayı, daha önce Karma Hakem Mahkemesinin önüne gelen davalardan daha büyük ve önemli addediyordu. ${ }^{33}$

Taraflar bu şekilde savunmaları için çalışmalara başlamışlardı. Kasım 1926'da Hıdivin vekili Hukuk Fakültesi Müderrislerinden Tahir Bey ${ }^{34}$ tarafından başvekâlete bir telgraf

3214 Temmuz 1874'te İskenderiye'de doğdu. Babası Mısır Hıdivi Tevfik Paşanın ölümü sonrası 1892'de Mısır Hıdivi tayin edildi. Başlangıçta İngiliz yönetimine karşıt bir politika izlediyse de uzun müddet bu tutumunu koruyamamıştır. Konuyla ilgili çalışmalar Hıdivin dengeli bir siyaset takip edemediğini belirtir. 1914'te İstanbul'a gelen Hıdiv savaşın da patlak vermesi ile bir daha ülkesine dönemedi. 19 Aralık 1914'te İngiltere'nin Misır'1 himayesi altına alması ile birlikte Abbas Hilmi, hıdivlikten azledildi ve yerine Hüseyin Kamil Hidiv tayin edildi. 15 Mart 1922'de Mısır bağımsızlık elde etti ve hıdivlik kaldırılarak Fuad "kral" unvanı ile yönetime geldi. Hıdivlik haklarını kaybeden Abbas Hilmi Paşanın malları da müsadere edildi. Paşa, 20 Aralık 1944'te Cenevre'de öldü. Bkz. İlhan Şahin, “Abbas Hilmi II” TDV İslam Ansiklopedisi, C. 1, İstanbul, 1988, s. 25-26.

Abbas Hilmi Paşa Birinci Dünya Savaşı süresince Almanya yanlısı politika izlemişti. Mckale çalışmasında, Hıdivin Birinci Dünya Savaşı boyunca hem İngiltere hem de Osmanlı açısından güvenilir bulunmadığına, takip ettiği politikalar nedeni ile tehlikeli görüldüğg̈ne işaret etmektedir. Mckale, ilaveten Hıdivin savaş boyunca Mısır tahtında yeniden hâkimiyet sağlamak için bağlantı kurmaya çalıştığına işaret eder. 1922 ve 1931 'de Fransızlarla Suriye tahtı için görüşmelerde bulunduğunu, 1923-1924'te Mısır kralı Fuad'1 Alman ve Misırlıların desteği ile devirmeye çalıştığını ama her ikisinde de başarısız olduğunu belirtir. İngiltere de bu süreç boyunca Hıdivin mallarını müsadere ederek etkisini ortadan kaldırmaya çalışmıştır. Bkz. Donald M. Mckale, "Influence without Power: the Last Khedive of Egypt and the Great Powers, 1914-18”, Middle Eastern Studies, C.33, S.1, 1997, s.21,34.

33 "Former Khedive's Property", "Claim Against the British Government",The Times, 21 Aralık 1926.

${ }^{34}$ Tahir Taner (1883-1956). Galatasaray Lisesini ve ardından 1905 'te Hukuk Fakültesini bitirmiştir. II. Meşrutiyet'in ardından Fransa'ya gönderilmiş ve orada hukuk eğitimi almış ve staj yapmıştır. 1913'te yurda dönmüş Adalet Bakanlığ1 bünyesinde çalışmıştır. 1918'de Hukuk Fakültesinde Ceza Hukuku kürsüsünde çalışmıştır. 1921'de Ankara'ya geçerek Adalet Bakanlığı müsteşarlığı yapmıştır. Bu görevi esnasında Lozan Konferansına adli müşavir olarak katılmıştır. Daha sonra Üniversitedeki görevine geri dönmüş, CMK Komisyonunda başkanlık yapmış, 
gönderilerek Abbas Hilmi Paşanın Mısır'da İngilizler tarafından el koyulan malları için İngiliz Hükümeti aleyhine Karma Hakem Mahkemesinde dava açıldığı belirtilmişti. Tahir Bey davada paşanın tabiiyetine itiraz edenlerin 23 Haziran 1900'de Misır Hıdivliğince neşredilmiş bulunan Mısır vatandaşlığını elde etmeye ilişkin bir emirnameye dayandıklarını belirtmiş ve kanun hükmünde sayılan bu emirnamenin eski hükümet tarafından kabul edilip edilmediğinin kendisine bildirilmesini istemişti. Aynı zamanda konuya ilişkin dosyaların birer suretini talep etmişti. Bundan sonra ilgili birimlerce hazine-yi evrakta bulunan emirnamenin incelenerek gerekli bilginin Tahir Beye verilmesi kararlaştırılmıştı. ${ }^{35}$

Türk-İngiliz Karma Hakem Mahkemesi Mayıs 1927 başında ilerleyen günlerde Abbas Hilmi Paşanın İngiliz Hükümeti aleyhine açtığı davanın görüleceğini duyurmuştu. Bu davaya büyük bir önem verilmekteydi. Abbas Hilmi Paşa Türk barosundan ve Fransız barosundan avukatlarca savunulacaktı. İngiliz Hükümeti dava ile meşgul olmak için İstanbul'a yeni bir ajan gönderecekti. Mahkeme salonunda bulunmak isteyen İngiliz ve Misır gazeteleri muhabirleri ile Türk matbuatı mensupları mahkeme reisine başvurarak mahkeme salonuna giriş kartı aliyorlard1. ${ }^{36}$

Mısır Hükümeti'nin önceki adli danışmanı Maurice Amos Mayıs'ın ilk günlerinde İstanbul'a geldi. Beraberinde Türk-İngiliz Karma Hakem Mahkemesindeki İngiliz ajanı Owen Wells, avukat Fitzmaurice ve Hazine memuru Bay Orme de vard. Amos davada İngiliz Hükümeti adına hareket edecekti. Abbas Hilmi Paşayı ise Tahir Beyin yanı sıra iki adet Parisli avukat savunacaktı; Jacques Kayzer ve Bergery. İngiliz Hükümeti, mahkemeden bu davaya bakmaya yetkili olmadığı kararı çıkartmak adına savaşacaktı. ${ }^{37}$

10 Mayıs'ta Abbas Hilmi Paşanın davasının görülmesine başlanıldı. Mahkemenin tarafsız mahkeme reisi Hammerich idi. Mahkemenin Türk hakemi Memduh Bey, İngiliz hakemi Grimston idi. Mahkemenin Türk ajanı Emin Ali Bey ve İngiliz ajanı Wells idi. ${ }^{38}$

Salon oldukça kalabalıktı; ancak eski Hıdiv duruşmaya katılmamıştı. Gazetecilerin yanı sıra Hariciye murahhası Nusret Bey, İngiliz sefarethanesi başkâtibi, Mısır konsolosu da mahkemede hazır bulunmuştu. Davanın tarafsız başyargıcı Hammerich davayı özetlemişti. Buna göre eski Hıdiv Mısır'da İngilizler tarafından el koyulan mallarına karşılık kendisine verilen bedele Lozan'ın 65 ve 66.maddeleri gereğince itiraz ederek yaklaşık 600 İngiliz lirası olan tasfiye bedelinin 2,823,802 İngiliz lirasına çıkartılması için hüküm verilmesini mahkemeden talep etmiştir.

Konuyla ilgili İngiliz tarafının soruları şu şekilde özetlenebilirdi: Abbas Hilmi Paşa davası ile ilgili mallar Lozan Antlaşması ile Osmanlı'dan ayrılmış olan topraklarda mıdır; Abbas Hilmi Türk tabiiyetinde midir; söz konusu mallar İngiliz Hükümetince tasfiye edilmiş veya istisnai tedbirlere dayandırılmış mıdır; Lozan Antlaşmasının 65.maddesinin birinci fıkrası uyarınca söz konusu mal halen mevcut ve teşhis edilebilir nitelikte midir.

Öncelikle mahkemede Abbas Hilmi Paşanın tabiiyeti konu olmuştu. ${ }^{39}$ Abbas Hilmi Paşa başvurusunda Türk tabiiyetinde olduğunu belirtmişti. İlk söz İngiliz Hükümetinin müdafaa

1927'de Hukuk Fakültesi Başkanlığı ve 1933'de Dekanlık yapmıştır. Aynı zamanda La Haye Mahkemesinin Türk üyesi olarak görev yapmıştır. Bkz. Galip Doğan, "Ord.Prof. Tahir Taner (1883-1956)", Terazi Hukuk Dergisi, C.2, S. 16, 2007, s. 183-185.

${ }^{35}$ BCA. Başbakanlık Muamelat Genel Müdürlüğü, 30.10.0.0./17.99.3., 6.11.1926.

36 "Muhtelit Mahkemede”, “Abbas Hilmi Paşa Davası”, Milliyet, 3 Mayıs 1927.

37 "Fomer Khedive's Claim", "Question Before the Court", The Times, 9 May1s 1927.

38 "Muhtelit Mahkemede", Hakimiyet-i Milliye, 11 Mayıs 1927.

39 "Muhtelit Mahkeme Sabık Hidivin Davasını Reviyyete Başladı", Milliyet, 11 Mayıs 1927; "Former Khedive's Property", "Suit Agaimst Great Britain", The Times, 12 Mayıs 1927.

$$
\text { (1) }
$$


vekili Maurice Amos'undu, konuşmasını Fransızca yapmıştı. Amos, Mısır'ın 29 Ekim 1914'te İngiliz himayesine girdiğini, bu nedenle Hıdivin İngiliz tabiiyetinde bulunduğunu, muhtelit mahkemenin İngiliz Hükümeti ile kendi tebaasından biri arasındaki anlaşmazlığa bakma hakkının olmadığını söylemişti. Dahası Amos, yarı resmi suretle aldığı malumata göre Mısır Hükümetinin eski Hıdivin tabiiyet değiştirmesini kabul etmediğini belirtmişti. Amos bu konuda "eski tanıdıklarından" olan Mısır başvekili Servet Paşaya bir mektup yazarak bilgi istemişti. Servet Paşa "Azizim Amos" diye başlayan mektubunda, eski Hıdivin tabiiyetine ilişkin Türk Hükümetine yazılan mektubun imza işlerinde gecikmeler olduğunu, Mısır Hükümetinin bu mektupla eski Hıdivin tabiiyet değiştirmesini kabul etmediğini belirtmekteydi. Amos, tabiiyet meselesinin Türk ve Mısır Hükümetleri arasında görüşülmekte olduğuna işaret etmekteydi.

Amos ilaveten Lozan Antlaşmasına göre davacının tazminat talep edemeyeceğini; nitekim tarafların tazminat taleplerinden feragat ettiklerini, antlaşmanın 65 ve 66.maddelerinde bu konuda açıklık olduğunu belirtmiş̧ir.

Amos savunmasında Lozan Antlaşmasının diğer barış antlaşmalarından esas itibariyle bir farkının olmadığını vurgulamış ve Versay, Nöyyi, Trianon ve Sevr antlaşmalarından bahsetmiştir. Amos, Versay Antlaşması gereğince kurulan Muhtelit Hakem Mahkemelerinin Lozan gereğince de kurulmuş olduğuna işaret etmiştir. Nihayetinde Lozan'in 58.maddesi gereğince her türlü tazminattan vazgeçildiğini belirtmiştir. Mahkeme başyargıcının müdahalesi üzerine toparlayan Amos davacının tazminat talep etme hakkı olmadığını, şu halde davacının ancak mallarının geri alınmasını talep edebileceğini, bunun da ancak mala sahip olan şahıs veya makama olabileceğini belirtecekti.

Amos, müttefiklerin Türkiye'den ayrılmış olan araziyi kendi himayeleri altında saydıklarını, Mısır'ın da Türkiye'den ayrıldığını, bunun 65.madde ile de uyumlu olduğunu, davacının bu konuda İngiliz Hükümeti aleyhine dava açamayacağını belirtmiştir.

Amos, Mısır'ın Lozan'dan önce 7 Kasım 1914'te Türkiye'den ayrıldığını, müttefiklerin bu durumu 1914 senesi sonunda tanıdıklarını, düşman devletlerin ise müttefiklerle imzaladıkları anlaşmalar ile Mısır'ın bağımsızlığını tanıdıklarını belirtmişti. Mısır meselesi Lozan'ın 19.maddesi ile çözümlenmişti. Lozan Antlaşması Mısır'a uygulanamayacağından Abbas Hilmi Paşanın davası Karma Mahkemede görülemezdi. ${ }^{40}$ 19.maddeye göre Mısır'ın tanınmasından doğan sorunlar, ilgili devletlerarasında sonradan kararlaştırılacak hükümlerle çözüme bağlanacak ve Lozan'ın Türkiye'den ayrılan topraklara ilişkin hükümleri Mısır'a uygulanmayacaktı. ${ }^{41}$

The Times, 19.madde uyarınca Türkiye'den ayrılan topraklara ilişkin sözü geçen antlaşma hükümlerinin Mısır'a uygulanamayacağı hükmünün Amos'un savunmasının en önemli argümanı olduğunu vurgulamıştı. Amos'un üç saat süren konuşmasının ardından Türk tarafını dinlemek üzere duruşma ertesi güne ertelendi. ${ }^{42}$

Mahkemenin ikinci duruşması ertesi gün, ayın 11 'inde gerçekleşti. Türk basınında yer alan yorumlara göre ikinci celse ilk celseden daha heyecanlı olmuştu. Bu kez söz Türk tarafındaydı. Abbas Hilmi Paşayı öncelikle Tahir Bey savundu. Savunmasını Fransızca yapan Tahir Bey açılan davanın Lozan'ın 65 ve 66.maddelerine dayandığııı belirtti.

\footnotetext{
40 "Muhtelit Mahkeme Sabık Hıdivin Davasını Reviyyete Başladı", Milliyet, 11 Mayıs 1927; "Former Khedive's Property", "Suit Agaimst Great Britain", The Times, 12 May1s 1927.

${ }^{41}$ Meray, age, s.7.

42 "Former Khedive's Property", "Suit Agaimst Great Britain", The Times, 12 May1s 1927.
} 
Tahir Bey, ilk olarak Abbas Hilmi Paşanın Türk tebaası olduğunu, ikinci olarak anlaşmazlığa konu olan emlakin Osmanlı'dan ayrılan ve 29 Ekim 1914'te İngiltere himayesi altında el koyulan toprakta olduğunu, üçüncü olarak bu emlakin tasfiyeye tabi tutulduğunu belirtti. Tahir Bey son iki noktanın aydınlatılmasını Maltres Bergery ve Kayzer'e bırakarak tabiiyet meselesini ele ald.

İngiliz Hükümeti 5 Kasım 1914 tarihine kadar davacının Türk tabiiyetinde olduğunu kabul ediyor, bu tarihten itibaren Türk tabiiyetinde olduğunu kabul etmiyordu. İngiliz Hükümetinin tezine göre o tarihte, Türkiye ile Misır arasında mevcut bağl1lıklar son bulduğu için yeni bir tabiiyet yani Mısır tabiiyeti ortaya çıkmıştı. Türkiye'nin Mısır ve Sudan üzerindeki her türlü hakkından feragati bu tarihten itibaren başlar ve herhangi bir şahsın tabiiyeti iki hükümet arasındaki uyuşmaya bağlıdır. Bu gibi bir uyuşma olmadığı takdirde 5 Kasım 1914 tarihinde Mısır'da bulunmuş olan yerliler Mısır tabiisi sayılacaktır.

Tahir Bey Türk tarafının tezini açıklarken adli mevzuatın yeterli gelmediğini, milli kanunlara başvurmak gerekliliğini belirtmiştir. Mısır'da bile tabiiyet meselesinin sağlam bir esasa dayanmayan bir mesele olduğunu belirten Tahir Bey en açık kanun olarak 26 Mayıs 1926 tarihli Misır kanunu göstermektedir. Bu kanuna göre 5 Kasım 1914'te Misır'da ikamet edenler ve bu tarihten itibaren Mısır'daki ikametlerini muhafaza etmiş olanlar Mısır tabiiyetini kabul etmiş sayılır. Tahir Bey, Abbas Hilmi Paşanın bu iki şartı da taşımadığını belirtmektedir. Buna göre Paşa, 20 Mayıs 1914'te Mısır'dan ayrılmış ve Avrupa seyahatinin ardından 22 Temmuz 1914'te İstanbul'a gelmiştir. 24 Temmuz'da Sadrazam ile görüşmesinin ardından Babıali'den çıkarken suikasta maruz kalmış ve bir ay İstanbul'da ikamet edip tedavi olmuştur. Bu sırada İngiliz sefarethanesi müsteşarı kendisini ziyaret ederek sağlığı nedeniyle Hıdivin İstanbul'da kalmasının iyi olacağını ve Mısır'da da Hıdivin bulunmasını gerektirecek bir durum olmadığını belirtmiştir. Sonunda 26 Eylül 1919'da İstanbul'un İngiliz sefiri Mallet, Hıdivin Mısır'a gidişinin İngiltere tarafından yasaklandığını resmen bildirmiştir. Hıdiv, bundan sonra Çubuklu'ya yerleşmiş ve Mısır'a da dönmemiştir.

Misır tabiiyet kanunun 5. ve 6.maddesi Abbas Hilmi Paşaya seçme hakkı vermektedir. $\mathrm{Bu}$ seçme hakkının süresi de yirmi gün sonra dolacaktır. Buna rağmen Abbas Hilmi Paşa bu güne kadar ve bundan sonra Mısır tabiiyetini seçme konusunda bir teşebbüste bulunmayı düşünmemektedir. Tahir Bey Türk tabiiyet kanunun da hıdivliğin, asıl tabiiyet olan Türk tabiiyetini kaybetmediğini belirttiğini ifade etmiştir.

Tahir Bey, Servet Paşanın mektubunu da ele almaktan geri durmamıştı. Bu mektubun mahkemeye önceden verilmeden yalnızca önceki aleni celsede okunmasından üstelik davalının ricası üzerine kaleme alınmasından dolayı mahkemece dikkate alınmamasını belirtmişti. Kendilerinin nizamnameye uygun olarak, vesikaları mahkemeye aleni celsede sunmak gibi bir davranış içine girmediklerini belirten Tahir Bey bu konuda davalı tarafı oldukça eleştirmişti. Bu konuda Lozan delegesi iken başına gelen bir olayı da örnek gösteren Tahir Bey, İngiliz heyetinin Lozan Antlaşması imzalanırken Türk heyetine bir mektup gönderdiğini, son dakikada gönderilen bu mektubun itibara alınmayacağından cevapsız kaldığını belirtmişti.

Amos'un eski dostu olan Servet Paşadan aldığı mektubun rica üzerine gönderilen bir mektup olduğunu vurgulayan Tahir Bey mektubun "yeni vazifenizde her muvaffakiyete mazhariyetinizi temenni ederim..." diye biten son sözlerinin bunun ispatı olduğunu belirtmişti. Amos bu duruma itiraz etmiş̧ir. Sözlerine devam eden Tahir Bey, Amos'un dünkü celsede Mısır ve Türk hükümetleri arasında tabiiyete ilişkin görüşmeler devam ettiği iddiası üzerinde de durmuş ve bu iddiayı yalanlamıştı. Türk Hükümetinin her hangi bir şahsın tabiiyeti ile ilgili bir devletle müzakerede bulunamayacağını belirtmişti. Gönderilen mektubun müzakere temelinde olmadığını, Türk Hükümetinin Abbas Hilmi Paşayı Türk tebaası saydığından dolayı 
bu mesele ile ilgili müzakere yapmayacağını belirtmiştir. Tahir Bey, Mısır Hükümetinin İngiliz Hükümetini zor bir durumdan kurtarmak için belki rica söz konusu olursa tüm sorumluluğu kabul eden bir mektup da gönderebileceğini; fakat mevcut tabiiyet kanunu karşısında özel mektupların bir öneminin olmadığını belirtmiştir.

Amos tarafından verilen beyan üzerine Türk tarafı Ankara'ya bir telgraf göndermiş ve İsmet Paşadan cevap almışlardır. İsmet Paşa telgrafa gönderdiği cevapta, Abbas Hilmi Paşanın tabiiyeti hakkında Mısır Hükümetinin itirazı olduğundan bilgilerinin olmadığını, Hariciye Vekâletinin Abbas Hilmi Paşanın tabiiyetine karşı itirazları barındıran bir mektubun sefarethanelerine verildiğinden haberi olmadığını belirtmişti. İsmet Paşa, Abbas Hilmi Paşanın tabiiyetine ilişkin bir şüphe olmadığını, bu konu hakkında müzakere yapılmasının mümkün olmadığını belirtmiştir.

Bundan sonra sözü Abbas Hilmi Paşanın avukatlarından Bergery almıştır. Bergery, Mısır'ın hangi şartlar altında Türkiye'den ayrıldığını açıklamaya girişmiştir. Lozan'ın 19.maddesinin Mısır Hükümetini alakadar eden davaların Mısır devletinin tanınmasından sonra halledilebileceğini kaydettiğini belirtmişti. Kendilerinin Mısır Hükümeti veya Devleti ile ilgilerinin olmadığını, davanın İngiliz Hükümeti aleyhine açıldığını bu nedenle davanın görülmesi için Lozan'ın 19.maddesine dayanarak Mısır devletinin tanınmasını kabul etmenin mümkün olmadığını ifade etmişti. Bu dava bir müsadere davasıydı ve 19.madde ile ilişkisi yoktu. Antlaşmasının 65 ve 66.maddelerine dayanmaktaydı.

Bergery'nin ardından sözü Kayzer almıştır. Kayzer, bir memleketin hem Türk hâkimiyetinde hem de İngiliz himayesinde bulunamayacağını, 1914 Kasım'ında Mısır'ın İngiliz himayesinde bulunduğunu belirtmiştir. Dahası 1920'de Misır'da meydana gelen kargaşalar hakkında araştırmada bulunmak üzere İngiliz Hükümetince Mısır'a gönderilen Lord Milner'ın "Mısır kuvvetli bir bahçıvana muhtaç bir çiçektir" demek suretiyle İngiltere'nin Mısır hakkında beslediği hislere tercüman olduğunu belirtmiştir. Kayzer, Amos'dan önce Misır Adliye Nezareti Müsteşarlığında bulunan İngiliz'in kargaşanın otuz beş senedir Mısır'da hâkim olan İngiliz nüfuzunun bir sonucu olduğunu söylediğini ifade etmiştir. Vefat eden bir Misırlı nazırın yerine bir İngiliz müşavir tayin edilirdi. Kayzer tüm bu delillerin Mısır'da meydana gelen hadiselerin sorumlusunun İngiltere olduğunu kanıtladığını belirtmiştir. Dolaysıyla Abbas Hilmi Paşanın mallarının müsaderesinden de İngiltere sorumludur. İlaveten söz konusu mallar bizzat İngiliz memurlarınca müsadere edilmiştir.

Kayzer bir örnek daha vererek Prens Kemalettin'in Misır'daki Karma Mahkemeye başvurarak müsadere edilmiş olan emlakinden dolayı zararının karşılanmasını talep ettiğginde Mısır Dâhiliye Nezaretinin söz konusu emlakin İngiliz Hükümetince müsadere edildiğini, sorumluluğun doğrudan doğruya İngiliz Hükümetine ait olduğunu beyan ettiğini vurgulamıştı. Karma Hakem Mahkemesi de bu davaya bakmamıştı. Bu deliller de gösteriyordu ki el koyma doğrudan İngiliz memurlarca yapılmıştı, sorumlu İngiltere idi. Emlaki iade edememesi durumunda İngiltere talep olunan meblağ ödemek zorundaydı.

Bergery de söz alarak Mısır'daki olaylardan İngiltere'nin sorumlu olduğunu belirtti. Amos ise iddiaları reddetmişti. Mısır'daki olaylara şahsen vakıf olduğunu belirtmişti. Buna göre Mısır Hükümeti ve İngiliz Hükümeti birbirinden ayrıydı. İlaveten Servet Paşadan alınan mektupla ilgili cevap veren Amos, İstanbul'a geldiği gün mektubu aldığı için mahkemeye önceden sunamadığını belirtmişti. İki hükümet arasında Hıdivin tabiiyetine ilişkin görüşmeler olduğunu yarı resmi kaynaktan öğrendiğini, bu görüşme hakkında bilgi almak için Servet Paşaya müracaat ettiğini ve istihbaratının sağlam olduğunu yineledi. 
Bundan sonra Mahkemedeki Türk ajanı Vasfi Raşid Bey Türk ajanlığının görüşünü içeren on dokuz sayfalık muhtırayı hâkimler heyetine vermiştir. Muhtırayı mahkemede okumamış; ancak karar sırasında muhtıranın mahkemece dikkate alınmasını belirtmiştir. Vasfi Raşid Bey, Amos tarafindan okunan mektubu duyar duymaz bu konuda Hükümetinden izahat istemek üzere harekete geçmişti. Aldığı cevapta Abbas Hilmi Paşanın Türk tabiiyetinde bulunduğu ve bu mesele hakkında hiçbir müzakere yapılmadığı bildirilmekteydi. Hariciye Vekili Tevfik Rüştü Beyin imzası bulunan telgrafta, Abbas Hilmi Paşanın Türk tabiiyetinde olduğu; Türk Hükümeti tarafından Mısır Hükümeti nezdinde yapılan itirazın tabiiyet kanununa dair olduğu yer alıyordu. Telgrafta ayrıca Kahire elçiliği ile Hariciye Vezareti arasında haberleşmeler olduysa da aslında Birinci Dünya Savaşının başlamasından önce İstanbul'da bulunan Hıdivin söz konusu kanunun 2. ve 3.maddeleri gereğince Misır tabiiyetinden sayılacaklar arasında olmadığı yer almaktaydı.

Vasfi Raşid Beyin izahatı ardından Mahkeme başkanı Hammerich karar için mahkemeyi başka bir güne erteledi. ${ }^{43}$

Karma Mahkeme hüküm vermeyi ertelemişti. Dosyanın "ahlaki” tarafı üzerinde durmak zorunda olduğunu belirten Bergery, İngiliz Hükümeti'nin Abbas Hilmi Paşaya karş1 sürekli bir kampanya başlattığını belirtmiş ve İngiliz Hükümetinin eylemini eleştirmeye başlamıştı. Bu konuda Amos araya girmiş, Bergery'nin yanlış beyanda bulunduğunu vurgulamıştı. Yargıç Hammerich de olaya müdahale etmişti. The Times, bu küçük çatışma hariç tüm dosyanın taraflar için güler yüzlü bir biçimde geçtiğini vurgulamıştı. Bergery'nin edebi çıkışları Amos'u gülümsetmişti. Davaya halkın büyük ilgisi olduğunu İngiliz basını da vurgulamıştı. The Times, yargıç Hammerich'in büyük bir görev aldığını; ancak Danimarka'nın her zaman ünlü olduğu adaletin yüksek prensiplerini sürdürmesine güvenilebileceğini belirtmişti. ${ }^{44}$

Türk Dışişleri Bakanlığı da davayı yakinen takip etmeyi sürdürdü. 8 Haziran'da Tevfik Rüştü imzasıyla Karma Hakem Mahkemesi umumi ajanlığına gönderilen telgrafta Türk-İngiliz Karma Hakem Mahkemesinde görülen Hıdiv Abbas Hilmi Paşaya ait davada Paşanın dava vekiliyle iletişime geçilerek gerekli bilginin alınması, hukuki tetkikatın yapılması ve hukukunun zayi olmaması için yetki dâhilinde ve hukuki çerçevede çalışılması rica edilmişti. ${ }^{45}$

\section{II. Abdülhamid'in Mirasçıları Davası}

II.Abdülhamit' in ${ }^{46}$ mirasçılarının Karma Hakem Mahkemesinde açtıkları dava, mirasçıların ilerleyen dönemde ortaya atacakları yurt içinde ve yurt dişındaki miras taleplerinin sadecel küçük bir başlangıcını oluşturmuştur. Bu aşamada II.Abdülhamit'in mirasçılarının, miras taleplerindeki dayanaklarını anlamak açısından II.Abdülhamit ve Meşrutiyet sürecindeki Hazine-yi Hassa yönetimine kısaca göz atmak gerekir. The Times gazetesine göre Abdülhamit'in saltanatı boyunca yaptığı en önemli iş imparatorluğun en değerli topraklarına el koymak ve bunları Hazine-yi Hassa'ya devretmek olmuştu. Bu şekilde Abdülhamit dünyanın en büyük toprak zenginlerinden biri haline gelmişti. Abdülhamit, hükümdarlığının sonlarında kendisi öldüğünde bu toprakların kendisinden sonra tahta geçenin olacağını fark etmiş bu şekilde toprakları kendi çocuklarına miras bırakmak ve Osmanlı hanedanın diğer üyelerinin

\footnotetext{
43 “Muhtelit Mahkemelerde Reviyyete Devam Edilen Dava”, “Abbas Hilmi Paşanın Müdafaa Vekilleri Paşanın Türk Tabiiyetinde Olduğunu ve Muhtelit Mahkemenin Bu Davayı Reviyyet Edebileceğini İspat Ettiler”, Vakit, 12 Mayıs 1927; “Abbas Hilmi Paşa Şartsız ve Kayıtsız Türk Tebaasıdır”, Milliyet, 12 Mayıs 1927; "Former Khedive's Property", "The Kedive's Case", The Times, 12 Mayıs 1927.

44 "Former Khedive's Property", "The Closing Arguments", The Times, 13 Mayıs 1927.

${ }^{45}$ BOA. HR. IM., $219 / 47$ 8.6.1927.

${ }^{46}$ II. Abdülhamid (1842-1018) 1876-1909 y1lları arasında hüküm sürdü. Bkz. Cevdet Küçük, “Abdülhamid II”, TDV Íslam Ansiklopedisi, C. 1, İstanbul, 1988, s. 216- 224.
}

to


dışlanması adına mülklerini kendi adına kaydetmek için adımlar atmıştı. Bir dönem Abdülhamit'in üçüncü ve en sevdiği oğlu Burhanettin Efendi yararına tahta çıkışla ilgili düzenlemeler yapacağı yönünde şayialar söz konusu olmuştu. ${ }^{47}$

II.Abdülhamit döneminde Hazine-yi Hassa idaresi bir bakanlık düzeyine çıkartılmış ve malvarlığ 1 genişletilmiştir. Bu dönemde Hazine-yi Hassa'ya devredilen arazilerin yüzölçümü ve sayısı önceki padişahlara oranla çok daha fazladır. $\mathrm{Bu}$ arazilerin büyük kısmı Mezopotamya' $\mathrm{da}^{48}$ olmakla birlikte sadece Mezopotamya ile sinırlı değildi. Anadolu ve Rumeli'de kurulan padişah çiftliklerinin sayısı yüz elliye varmış, bu faaliyetler Suriye, Irak, Bingazi'ye kadar yayılmış, bu varlıklara maden işletme ve vapur işletme gelir kaynakları da katılmıştır. ${ }^{49} 1889$ yılında çıkartılan bir irade ile Musul'un tamamında petrol kaynaklarının işlenmesi hakkı Devlet Hazinesinden alınarak Padişah'ın Hazine-yi Hassa' sına devir edilmiştir. Padişah, Eylül 1898 yılında çıkarttığı ikinci bir fermanla Güney Mezopotamya petrol yataklarını da Hazine-yi Hassa'ya devretmiştir. Bu şekilde Bağdat Vilayeti petrolleri de padişahın özel mülkü olmuştur. ${ }^{50}$

II. Meşrutiyet'te ise süreç tersine dönmüştür. İttihat ve Terakki'nin iş başına gelmesini takiben Eylül 1908'de çıkartılan bir irade ile Hazine-yi Hassa tasarrufunda bulunan bir takım emlakin ve petrol haklarının Devlet Hazinesine devri sağlanmıştır. II.Abdülhamit' in tahttan indirilmesi ve Sultan Reşad'ın tahta çıkışını takiben Mayıs 1909'da Hazine-yi Hassa varlıklarını Devlet Hazinesine aktaran yeni bir ferman çıkartılmıştır. ${ }^{51}$

Sultan Vahdettin döneminde ise Mondros Mütarekesi ardından gelişen işgal sürecinde Ocak 1920'de yayınlanan geçici kararname ile Eylül 1908 ve Mayıs 1909 tarihli fermanlarla Devlet Hazinesine aktarılan Hazine-yi Hassa emlaki yeniden Hazine-yi Hassa'ya iade edilmiştir. Sultan Vahdettin bu mülklerin çoğunun müttefiklerce işgal edilen yerlerde olduklarını ve

Volume 12

Issue 2

A Tribute

to Assoc.

Prof. Dr.

Illknur

Mangır

Karagöz,

April

2020

Türklerin bu bölgeleri kaybetmek üzere olduklarını fark etmişti. Oysa Hazine-yi Hassa'ya ait olursa şahsa ait olacağından işgale tabi tutulmayacağı hesap olunmuştu. ${ }^{52}$ BMM'nin çıkarttığ 1 Kasım 1920 tarihli yasa ile Hazine-yi Hassa'ya iade edilen emlak, arazi ve ayricalıklar yeniden Devlet Hazinesine devredilmiştir. ${ }^{53}$

Konu Lozan görüşmeleri sırasında da gündeme gelmişti. II.Abdülhamit'in mirasçılarının temsilcisi Amerikalı iş adamı Untermyer, İsmet Paşayı ziyaret ederek Abdülhamit'in Makedonya'dan Irak'a kadar çeşitli bölgelerde geniş arazi ve mülkleri olduğunu söyledi. Anılan malların çoğu şimdi Türkiye dışındaydı. Untermyer hem mirasçıların haklarını korumak hem de Türkiye'ye pay sağlamak arzusunda olduğunu belirtmişti. İsmet Paşa petrol arazisinin bir kısmı elden çıksa bile mirasçılar Türk uyruğu olduğundan mal varlığının kendilerine dönmüş olacağını hesap ederek konuya olumlu yaklaşmıştı. Başbakan Rauf Beyin görüşü Abdülhamit'in Türkiye sınırları dışında kalan emlak ve arazisinin mirasçılara ait olduğunu kabul etmenin uygun olabileceği; buna karşıllk mirasçıların milli sınırlarda kalan emlak ve

\footnotetext{
47 “Abdul Hamid's Heirs", "Story of the Claim”, The Times, 17 Aralık 1930.

${ }^{48}$ Hiket Uluğbay, Imparatorluk'tan Cumhuriyet'e Petropolitik, De Ki Basım Yayım Ltd.Şti., Ankara, 2008, s.35

${ }^{49}$ Vasfi Şensözen, Osmanoğulları'nın Varlıklarl ve II. Abdülhamid'in Emlaki, TTK Basımevi, Ankara, 1982, s. 3-4, 48.

${ }^{50}$ Uluğbay, age, s. 41, 48.

${ }^{51}$ Cemil Koçak, II. Abdülhamid'in Mirası, ARBA Yayınları, İstanbul, 1990, s. 13-14; Sensözen, age, s. 64, 70-71; Uluğbay, age, s. 85, 89; Abdul Hamid's Heirs", "Story of the Claim", The Times, 17 Aralık 1930.

52 Uluğbay, age, s.238; Koçak, age, s. 14-15; Abdul Hamid's Heirs", "Story of the Claim”, The Times, 17 Aralık 1930.

${ }^{53}$ Uluğbay, age, s. 247.
} 
arazinin Türkiye'ye aidiyetini kabul etmeleri gerektiği yönündeydi. Musul ulusal sınırlar içinde olduğundan şimdilik bir yükümlülüğe girilmemeliydi. ${ }^{54}$

Bundan birkaç gün sonra gerçekleşen Lozan'daki oturumda Türk temsilciler, Hazine-yi Hassa mallarının özel mülk olarak değerlendirdiklerini vurguladılar. Müttefik Devletler ise bu malların 1908'den bu yana Devlet Hazinesine ait olduğunu belirtmekteydi. İsmet Paşa Türk Devleti'nin özel malları ile Hazine-yi Hassa mallarının Türkiye'ye iadesini talep etti. ${ }^{55}$ Lozan'da Türkiye ile müttefikler arasında bu mesele uzun bir süre tartış1ldı. Sonuçta Lozan'ın 60.maddesinin ikinci fikrası kaleme alındı. ${ }^{56}$ Buna göre Balkan Savaşları ardından ve işbu antlaşma ile kendilerine Osmanlı'da toprak parçası ayrılan devletler, Osmanlı'dan aldıkları bu toprak parçasında bulunan her türlü taşınır ve taşınmaz malları, karşılık ödemeksizin, elde etmiş olacaklardı. 8 Eylül 1908 ve 2 Mayıs 1909 tarihli iradelerde, Hazine-i Hassa'dan devlete geçirilmesi buyrulmuş olan taşınır ve taşınmaz mallarla, 30 Ekim 1918 de, bir kamu hizmeti yararına Hazine-i Hassa'ca yönetilen mallar yukarıda belirtilen taşınır ve taşınmaz malların kapsamı içinde bulunmaktadırlar. ${ }^{57}$

Mirasçıları ilgilendiren bir başka gelişme de 3 Mart 1924 tarihli Halifeliğin kaldırılmasına dair kanunun 4.maddesi ile Osmanlı hanedanına dâhil erkekler, kadınlar, damatlar ve hanedana mensup kadınlardan mütevellit kimselerin Türkiye Cumhuriyeti vatandaşlı̆g 1 sıfatı ve hukukunun kaldırılmasıydı. 2.madde ile hanedana mensup kişilerden sadece gelinler Türkiye'de kalabilecekti.

Lozan sürecinden aradıklarını bulamayan varisler Lozan sonrası dava açma yoluna gittiler. Abdülhamit'in Türkiye dışında kalan emlakinden senelik 20,000,000 İngiliz lirası gelir elde edilebileceği hesaplanmıştı. Dava konusu da en çok İngiltere'yi ilgilendiriyordu çünkü taleplerin olduğu bölgelere daha çok bu devlet hâkimdi. 3 Mart 1924 tarihli yasa uyarınca yurtta kalabilen II.Abdülhamit'in mirasçılarının ilk teşebbüsü İngiliz, Fransız ve İtalyan Karma Hakem Mahkemelerine başvurmak oldu. ${ }^{58}$

Bu şekilde Türk-İngiliz Karma Hakem Mahkemesinde görülen bir diğer önemli dava Abdülhamid'in mirasçıları tarafından 1930 yılında açılan dava oldu. 22 Kasım 1930'da duruşmaya başlandı. Mahkeme başkanı yine Hammerich idi. Mahkemenin İngiliz üyesi Hill, Türk üyesi Memduh Bey idi. İngiliz Hükümeti mahkemedeki İngiliz ajanı Owen Well ve Hazine'nin avukatı John Foster tarafından temsil edilmişti. İngiltere'den talep ettikleri mülklerin büyük kısmı Musul ve Irak’ta petrol sahalarındaydı. ${ }^{59}$

Abdülhamit'in mirasçılarını eski mebuslardan Mazliyah Efendi temsil etmişti. Bu davada da salon çok doluydu. İngiliz sefarethanesi memurları duruşmaya gelmişlerdi. Abdülhamit'in varisleri babalarından kendilerine kalıp Irak'ta bulunan mal ve emlakin kendilerine iadesini talep ediyorlardı. Bu taleplerinde Lozan'ın 60.maddesine dayanmaktaydılar. İngiliz Hükümetinin davaya ilişkin itirazları vardı. İlk söz Foster'ındı. Fransızca konuşan Foster itirazları dile getirdi. Buna göre;

1-Dava antlaşmanın tayin ettiği süre zarfında yapılmamıştı.

\footnotetext{
${ }^{54}$ Bilal Şimşir, Lozan Telgrafları I (1922-1923), TTK Basımevi, Ankara, 1990, s. 294, 312; Uluğbay, age, s. 291, 293.

55 Koçak, age, s. 16-19; Seha Meray, Lozan Barış Konferansı Tutanaklar- Belgeler, Üçüncü Komisyonun Tutanaklart ile Raporları (İktisat ve Maliye Sorunlart), Birinci Takım, C. III, YKY İstanbul, 1993, s. 71, 282-283

56 “Abdul Hamid's Heirs", "Story of the Claim", The Times, 17 Aralık 1930.

${ }^{57}$ Meray, İkinci Takım, C. II, s.20-21

${ }^{58}$ Şensözen, age, s. 79, 96-98; Koçak, age, s. 22-24, 106-107

59 “Abdul Hamid's Heirs", "Claim Against British Government”, The Times, 24 Kasım 1930.
} 
2-Vekâlet uygunsuzdu; nitekim Mazliyah, Günzberg Beyden vekâlet almıştı. O da doğrudan varisin vekili Halil Refet, Şevket, Saracettin ve Arif beylerden vekâlet almıştı. Bu şekilde üçüncü elden vekâlet almak caiz değildi.

3-Davacı varisler on iki kişiden oluşmaktayken tüm mirasın verilmesi için dava açmışlardı. $\mathrm{Bu}$ şekilde dava açmak için mahkemeye gelmeyen diğerlerinin de izin ve yetkilerinin alınması gerekirdi. Bu yüzden İngiliz tarafına göre davının reddi gerekiyordu.

4-3 Mart 1924 tarihli kanun ile Osmanlı hanedanına mensup olanlar Türk tabiiyetinden çıkartılmışlardı. Bundan dolayı Karma Mahkeme davaya bakamazdı.

5-Dava Lozan Antlaşmasının 60.maddesinde geçen iki iradenin söz konusu ettiği mallara ilişkin olduğundan, Hazine-yi Hassaya ait olan bu mallar 60.maddenin ikinci fikrası gereğince Osmanlı Devleti'nin yerine geçen devlete bedelsiz intikal ettiği için davanın bu sebepten de reddi gerekmekteydi. Davacılar taşınmaz malların iadesi için Lozan'ın 65.maddesine dayanamazlardı; çünkü bu maddede belirtilen istisnai savaş tedbirlerinin hedefi değillerdi.

Tüm bunlara karşı Nesim Mazliyah'ın müdafaası da aşağıdaki gibi olmuştu;

1-Mazliyah davanın kanuni süresi içerisinde yapıldığını belirtmiş, gösterilen deliller neticesinde Foster bu itirazdan alenen vazgeçmişti.

2-Mazliyah, vekâleti Sami Günzberg'den ve onun da yukarıda sayılan kişilerden aldığını söylemiş ve her vekilin diğerini vekil etmeye yetkili olduğunu belirtmiş, bunun dava sırasında yürürlükte olan Mecelle'nin 1466.maddesine ve Türk Medeni Kanunun 190.maddesine uygun olduğunu vurgulamıştır.

3-On iki kişiden oluşan davacıların, toplamı yirmiye ulaşan varislere ait olan mirasın

Volume 12

Issue 2

A Tribute

to Assoc.

Prof. Dr.

İlknur

Mangir

Karagöz,

April

2020 tamamını istemelerinin caiz olmadığ $\breve{1}_{1}$ konusunda Mazliyah Efendi, Mecellenin 1642.maddesine göre ölenin leh ve aleyhinde olan davada yalnız varislerden biri hasım olabilirken on ikisinin birden hasım olabilmesinin haydi haydi caiz olduğunu, mahkemenin davacılara ait olan hakları hükmetmekle mükellef olduğunu belirtmiştir.

4-Tabiiyet meselesine gelindiğinde Mazliyah Efendi, Mart 1924 tarihli hanedan kanununun 4.maddesinin hanedana mensup olanların vatandaşlık hukukunun ortadan kaldırıldı̆̆ını söylediğini, tabiiyetten çıkartıldıklarını söylemediğini belirtmişti. TBMM, tabiiyetten çıkartmaya yönelik bir kanun yapamazdı. Teşkilat-1 Esasiyenin 81.maddesinde hiçbir Türk vatandaşının kanunun tayin ettiği haller dışında tabiiyetten çıkartılamayacağı yer almaktaydı. Kanunun tayin ettiği ahval ise 28 Mart 1928 tarihli tabiiyet kanununda gösterilmekteydi. Hanedan ailesi tabiiyet kanununda gösterilen nedenlerden mahkûm olmamıştı. Bir kişi kendi arzusu ile tabiiyetten çıkamayacağı gibi tabii olunan bir vatandaş da kanunun tayin ettiği haller dışında tabiiyetten çıkartılamazdı.

5-Lozan Antlaşmasının 60.maddesi iki fikradan oluşmaktaydı. Buna göre birinci fikra bir prensibi, ikinci fikra o prensibin istisnasını zikretmekteydi. Birinci fikrada, bu antlaşma ile Türkiye'den ayrılan arazi üzerinde olup Türk Hükümetine ait olan mal ve emlakin bedelsiz şekilde lehlerine arazi ayrilan hükümetlere terki yer almaktadır. İkinci fikrada ise Abdülhamit'in varislerine ait olup 18 Eylül 1908 ve 2 Mayıs 1909 tarihli iradelerde geçen malların aynı şekilde bununla birlikte kendi yerine başkasını tayin ederek İtilaf Devletlerine terkedildiği gösterilmektedir. Mazliyah Efendi, bu iradelerde mevzu malların Türk Hükümetine ait olan diğer mallar gibi bedelsiz ve şartsız terki kastedilmiş olsaydı Lozan'ın 60.maddesine iki fıkra ilavesine lüzum olmayacağını belirtmişti. Mazliyah, söz konusu mülklerin istisnai savaş tedbirlerinin konusu olduğunu vurgulamıştı. Lozan zabıtlarında görülebileceği üzere Türk tarafı hep mal ve emlakin şahsi olduğunu ve bedelsiz terk edilemeyeceğini savunmuştu. Mazliyah 
Efendi son olarak söz konusu iki iradenin hükmünün olmadığını; nitekim 8 Ocak 1920 tarihli kanunla bu iradelerin ortadan kalktığını belirtmiştir.

Mahkemenin Türk ajanı Naşid Bey, II.Abdülhamit'in oğulları ve kızlarının Mart 1924'teki kanunla Türk vatandaşlığından çıkartıldığını; ancak dul eşlerinin halen vatandaş olmayı sürdürdüğünü belirtmişti. Naşid Bey, Mazliyah'ın argümanını desteklemişti. İngiliz ajanı Owen Well ise Foster'ın argümanını desteklemişti. Mahkemenin kararını Aralık ortasında vermesi umulmaktayd ${ }^{60}$

Abdülhamit'in mirası ile ilgili Karma Mahkemelerdeki dayanak Lozan'ın 60.maddesi olmuştu. Türk Hükümeti Abdülhamit'in varislerinden Türk tabiiyetinde kalan kadınların hukukunu göz önünde bulundurarak, 60.madde ile ilgili hukuki bir vesikayı Türk ajanlığına iletmişti. Türk Hükümeti, Başajanlığa, Bakanlar Kurulu kararı ile tebliğde bulundu. "Muhtelit Hakem Mahkemesi Umum Ajanlığına" başlığı ile 2 Aralık tarihinde gönderilen bu tebliğde, Lozan Antlaşmasının görüşülmesi sırasında bu antlaşmanın 60.maddesi gereğince Yunanistan'daki emlaktan başka Türkiye dışındaki yerlerde diğer devletlere kalan ve devletler tarafından şahsi emlak sayılan Abdlhamit varislerinin mal ve emlakını içeren listenin Türkİngiliz hakem mahkemesine sunulmak üzere verilmesine Bakanlar Kurulu tarafindan karar verildiği yer alıyordu. ${ }^{61}$

Sözü edilen Kasım 1930 tarihli Bakanlar Kurulu kararının ardından Ağustos 1931 tarihli Bakanlar Kurulu toplantısında II.Abdulhamit'in varislerinden Bedri Felek ve Müşfika kadınlar gayri mübadil sayıldıklarından mallarına kıymet takdir edileceğinden tapu senetlerinin taraflarına verilmesi yönündeki talepleri üzerine Maliye, Hariciye ve Adliye Vekâletlerinden alınan mütalaalar incelendi. Burada, mirasçılar gayri mübadil olduklarından Lozan'ın 60.maddesinin son fikrası gereğince Yunanistan'da kalan Hazine-yi Hassa adına kayıtlı emval ve emlakin hukuki mahiyeti değişmeyeceğinden Türklere verilen menafiden yararlanabilecekleri ve Hilafetin ilgasına ve Hanedanın sınır dışına çıkarılması hakkındaki kanunun kapsamı dışında ve Türk vatandaşlığı hukukunun tamamında istifade hakkı olmaları nedeniyle kendilerine intikal eden gayrimenkul malların kayıtlarının verilmesi lazım geldiğine karar verilmiştir.

Görüldüğ̈̈ üzere Türkiye Lozan sonrasında da Türkiye dışında kalan topraklarda Abdülhamit'in gayrı menkullerinim mirasçılarına geçmesini desteklemiştir. Bu sırada mirasın Türkiye'de kalan kısmı gündeme gelmemekteydi. ${ }^{62}$

Abdülhamit'in mirasçıları sadece Türk-İngiliz Karma Hakem Mahkemesine başvurmamışlardı. Varisler, İtalyan ve Fransızların elinde bulunan arazi ve emlakin iadesi için Türk-İtalyan ve Türk-Fransız mahkemelerinde de dava açmışlardı. ${ }^{63}$ Türk-Fransız Karma Hakem Mahkemesi diğerlerinden önce kararını açıklamıştı. Davacılar, Fransa Hükümetinden Suriye, Halep, Beyrut ve Lübnan'daki arazilerin kendilerine ait olan hisselerini talep etmişlerdi. Mahkemede Abdülhamit'in kızları ve oğullarının Mart 1924 kanunu ile Türk tabiiyetinden çıkartıldıkları ve eşlerinin de Lozan'ın 65.maddesindeki istisnai harp tedbirlerinden olmaması nedeniyle davaya bakmaya yetkili olunmadığı yönünde karar verilmişti. ${ }^{64}$

\footnotetext{
60 “Türk-İngiliz Mahkemesinde Abdülhamidin Emlakine Ait Davaya Başlandı”, "Dünkü Müdafaa Çok Hararetli Oldu, Kuvvetli Müdafaalar Yapıldı”, Cumhuriyet, 23 Teşrinisani 1930; “Abdul Hamid's Heirs”, “Claim Against British Government", The Times, 24 Kasim 1930.

61 "Abdülhamit Veresesi Davasında Yeni Vaziyet", "Hükümet Emlaki Şahsiyeden Olan, Vereseye Ait Malların Listesini Türk-İngiliz Mahkemesine Tevdi Etti”, Cumhuriyet, 3 Kanunuevvel 1930.

${ }^{62}$ Koçak, age, s. 24-26.

63 "Muhtelit Mahkemelerde”, “Abdülhamit Veresesi Davası”, Cumhuriyet, 2 Kanunuevvel 1930.

64 “Abdülhamit Veresesinin Açtı̆̆1 Dava”, “Adem-i Salâhiyet Kararı Verildi”, Cumhuriyet,10 Nisan 1930.
}

to


Türk-İngiliz Karma Hakem Mahkemesinde davanın görüldüğü Aralık ayında aynı zamanda Türk-İtalyan mahkemesinde de dava görüşmeleri sürmüştü. Mirasçıların talepleri Bingazi ve Oniki Ada'daki mülklere ilişkindi. Mirasçıların avukatları yine Nesim Mazliyah idi. İtalyan Hükümetinin vekilinin da savunması İngiliz Hükümeti vekili ile benzerdi. İtalyan vekil, varislerin verdikleri arzuhalde dava konusunun açıkça gösterilmediğini; Mazliyah'ın vekâletinin kanuni olmadığını; davacılar eski hanedana mensup olduklarından Mart 1924 tarihli kanunla Türk tabiiyetinden çıkartıldıklarını dolayısıyla mahkemenin bu davaya bakmaya yetkili olmadığını; Lozan'ın 60.maddesinin bu meseleyi çözdüğünü, Abdülhamit'in mirasçılarına ait taşınır ve taşınmazların İtalyan Hükümetine parasız terkedileceğini belirtmişti.

Mazliyah İtalyan vekilin iddialarına karşın her şeyin usulüne uygun olduğunu belirtmişti. İlaveten savunması mevcut kanunun onları Türk tabiiyetinden çıkartmadığı, vatandaşlık hukukunu ortadan kaldırdığı yönünde olmuştu. Mazliyah, tabiiyetle vatandaşlı̆̆ın ayrı şeyler olduğunu, TBMM'nin tabiiyetten çıkartmaya ilişkin kanun yayımlayamayacağını; çünkü anayasanın 88.maddesinde Türk vatandaşlarının ancak kanunun tayin ettiği şartlar dairesinde vatandaşlıktan çıkartılacaklarının yer aldığını belirtmişti. Bu durumlar da tabiiyet kanununda gösterilmiştir. Mazliyah, eski hanedana ait kimselerin tabiiyet kanunundaki şartlar dairesinde mahkûm olmadıkları için tabiiyetten çıkartılmaları için haklarında kanun yapılamayacağını belirtmişti. Son olarak Mazliyah, İtalya'nın Lozan'ın 60.maddesini yanlış yorumladığını belirtmiştir. $\mathrm{Bu}$ maddenin ikinci fikrasında mal-mülk meselesinde İtalya Hükümetinin Türk Hükümetinin yerine geçtiği yer almaktadır. Türk Hükümeti bu mallar konusunda nasıl varislerin davalarına maruz kalmışsa İtalyan Hükümeti de bu davalara maruz kalmalıydı. Lozan görüşmelerinde söz konusu malların özel mülk olması dolayısıyla kazanan devletlere para karşıllığ devredilemeyeceği, bunların hukukuna uymak gerekliliği yer almıştı. ${ }^{65}$

Volume 12

Issue 2

A Tribute

to Assoc.

Prof. Dr.

İlknur

Mangir

Karagöz,

April

2020

\section{Davaların Sonuçlanması}

29 Haziran 1927 tarihli duruşmada Mahkeme, Hıdivin ve Malta sürgünlerinin İngiltere aleyhine açtıkları davaları reddetmiştir. Davanın sonucunu Cumhuriyet gazetesi " $\mathrm{Bu} \mathrm{mu}$ Adalet" başlığı ile vermiştir. Milliyet gazetesi ise haberi "Bu Karara Hiç Diyecek Yok" başlığı ile duyurmuştu.

Türk-İngiliz Karma Mahkemesi Hıdivin davasında Lozan Antlaşmasının 19.maddesi üzerinde durmuş ve buna geniş bir anlam vermişti. Buradan yola çıarak 65.maddede geçen iade veya 66.maddede yer alan tasfiye bedelinin arttırılması mükellefiyetinin, iadesi lazım gelen malların bulunduğu yerin ilgili hükümetin bugün nüfuzu veya hâkimiyeti altında bulunması ile ancak geçerli olacağını ortaya koymuştur.

Mahkeme davacının tabiiyeti ve alınan tedbirlerin mahiyeti hakkında tahkikata gerek görmeksizin davayı görmeye yetkili olmadığına ve 200 lira mahkeme masrafı ile 500 lira şahsi masrafın davacıdan alınmasına karar verilmiştir.

Bundan sonra Karma Mahkeme, Ahmet Emin Beyin davasını gündeme almıştır. Mahkeme, 1 Ağustos 1914'ten antlaşmanın yürürlüğe girdiği döneme kadar olan savaş eylemlerinden dolayı antlaşmayı imzalayanların her türlü nakdi tamirat külfetinden 58.madde dolayısıyla azade tutulduklarına ve ismi geçenin sürgün vaziyetinin savaş eyleminden olduğunun aşikâr olduğuna kanaat getirmiştir. Mahkeme bu davayı da reddederek Ahmet Emin Beyi 240 lira masraf itasına mahkûm etmiştir.

65 “Abdülhamit Veresesinin Davasına Dün Bakıldı”, “Türk-İtalyan Mahkemesinde İki Taraf Vekilleri Müdafaalarını Yaptılar”, Cumhuriyet, 4 Kanunuevvel 1930. 
Mahkeme Malta sürgünlerinden emekli Miralay Celal Bey davasını da incelemiş ve bu dava hakkında da aynı sebepten ve alıkonulmuş esaret maaşı hakkında 65.maddenin sadece el konulan mallara ilişkin olduğu suretle davaya bakmaya yetkili olmadığ 1 yönünde karar vermiştir. Davacıyı 100 lira mahkeme masrafı ile 500 lira şahsi masraf itasına mahkûm etmiştir. $^{66}$

Yalman anılarında açılan dava konusuna şu şekilde değinmiştir;

“Lozan Sulhu'nden sonra kurulan Muhtelit Mahkeme'de hepimiz, kurbanı olduğumuz zulümden dolayı davacı olduk. O sıralarda avukatlı eden eski Maarif müsteşarı Prof Muslihittin Adil Bey, yüzlerce davaya bir örnek olmak üzere benim davamı üzerine aldl; pek iyi savundu, fakat Muhtelit Mahkeme salahiyetsizlik iddiasiyle işin içinden siyrıldı. ",67

Görüldüğü gibi davacılar davalarını kazanamadıkları gibi bir de mahkeme masrafı ödemek durumunda kalmışlardır. Abbas Hilmi Paşanın ve Malta sürgünlerinin davasının sonucu İngiliz basınında da yer buldu. Mahkemenin kendisini davalara bakmaya yetkisiz olduğu sonucuna vardığı basında konu edildi davacının başarısız olduğunun söylenebileceği belirtildi. ${ }^{68}$

Mahkeme Başkanı Hammerich, dava dilekçesi vermiş diğer Malta sürgünlerine de bu ilk yetkisizlik kararını takiben ayrı ayrı mektuplar yazarak davalarını takip edip etmediklerini sormuş ama cevap alamamıştır. Bundan sonra Mahkeme, Malta sürgünlerinden altmış üç kişinin dava dilekçelerini iptale karar vermiştir. Kararın gerekçesinde Mahkemenin, Lozan Antlaşması gereğince işlerini bir an önce bitirmeye mecbur olduğu hâlbuki dilekçe sahiplerinin dilekçelerini takip etmediklerini belirtmişti. ${ }^{69}$

Abbas Hilmi Paşanın tabiiyeti meselesi ise dönem dönem gündeme gelmeyi sürdürdü. ${ }^{70}$

Abdülhamit'in mirasçılarının Türk-İngiliz ve Türk-İtalyan Karma Hakem Mahkemesinde açtıkları dava 16 Aralık 1930'da sonuçlandı. Karma Hakem Mahkemesi bu olayın Lozan'ın

66 "Bu mu Adalet”, “Türk- İngiliz Mahkemesi”, Cumhuriyet, 30 Haziran 1927; "Bu Karara Hiç Diyecek Yok", Milliyet, 30 Haziran 1927. Hakimiyet-i Milliye gazetesinin konuya dair haberinde Celal Beyden 170 lira mahkeme masrafı alınmasına hüküm verildiği yer almakta. Bkz. "İngiliz Muhtelit Hakem Mahkemesinin Verdiği Karar", Hakimiyet-i Milliye, 30 Haziran 1927.

${ }^{67}$ Ahmet Emin Yalman, Yakın Tarihte Gördüklerim ve Geçirdiklerim, Haz.: Erol Sadi Erdinç, C. I, Pera Turizm ve Ticaret A.Ș., İstanbul, 1997, s. 668.

68 "Former Khedive's Action Against Britain", "Failure of the Claims", The Times, 30 Haziran 1927.

69 "Malta Menfileri”, “Davalarını Takip Etmeyenlerin İstidaları İptal Edildi”, Milliyet, 3 Temmuz 1928.

${ }^{70}$ Eski Hıdive Cumhuriyet döneminde Türk diplomatik pasaportu verilmiș ve bu pasaport ile Hıdiv Avrupa'ya seyahat etmiştir. 21 Aralık 1949 tarihli TBMM oturumunda Ahmet Remzi Yüregir, Abbas Hilmi Paşanın vefatı ardından Dışişleri Bakanlığının merhumun dış ülkelerdeki hukuki durumu adına ve Maliye Bakanlığının Paşadan kalan mallar için Hazineye vergi tahsili adına adım atıp atmadığına dair bir soru önergesi vermiştir. Dışişleri Bakanı Necmettin Sadak, bir ara Abbas Hilmi Paşaya "cemile" olarak Türk diplomatik pasaportunun verildiğini; fakat bunun Hıdivin hiçbir zaman Türk tabiiyetine girmesi anlamını taşımadığını, kendisinin hiçbir zaman Türk tabiiyetine girmediğini belirtmiştir. Türkiye Cumhuriyeti Hükümeti ile Mısır Hükümeti arasında 1937'de imzalanan Tabiiyet Mukavelesi gereğince Türkiye'nin, Abbas Hilmi Paşanın Mısır tabiiyetinde tanınmasını taahhüt ettiğini belirtmiștir. Yüregir ise devlet hukuku açısından "cemilenin" mevzu olamayacağını Hıdivin Atatürk tarafından verilmiş bir nüfus hüviyet cüzdanına sahip olduğunu, Cumhuriyet döneminde ona daimi bir diplomatik pasaport verildiğini ve bu şekilde başka memleketlerde oturmasının sağlandığını belirtmiştir. Yüregir burada Abbas Hilmi Paşanın kendisini Türk tabiiyetinde görerek Türk-İngiliz Karma Hakem Mahkemesine dava açtığını, İngiliz Hükümetine karşı kendisinin Türk tabiiyetinde olarak zarar gördüğünü iddia ettiğini belirtmiştir. Yüregir bu süreçte Hıdivin avukatı Tahir Taner ile de mektuplaşmıştır. Bu vesika ile Hıdivin Türk tabiiyetinde olduğunun sabit olduğunu belirtmiştir. Sadak ise Hıdivin pasaport alabileceğini, nüfus cüzdanı alabileceğini; ancak Türk tebaası olamayacağını 1937 antlaşmasını göstererek yinelemiştir. İçişleri Bakanı Emin Erişirgil de Dışişleri ile Mısır Elçiliği arasındaki mektuplaşmalar ile Mısır Hıdiv ailesine mensup olanların Türk tabiiyetinde olmadığının kabul edildiğini vurgulamıştır. Bkz. Türkiye Büyük Millet Meclisi Tutanak Dergisi, Dönem: VIII, C. 22, Toplantı: 4, Yirminci Birleşim, 21.12.1949, s.337-343. 
65.maddesinde geçen istisnai savaş tedbirleri içerisinde olmadığına hükmetti. Bu toprakların Lozan'ın 60.maddesinde belirtildiği üzere Abdülhamit tarafından 1908 ve 1909 tarihli iradelerle Türk Hükümetine devredildiğini belirtti. Bu şekilde Mahkemeler, mirasçılar tarafından geri alınması talep edilen taşınır ve taşınmaz malları Lozan Antlaşmasının 60.maddesinin ikinci fikrasına uygun olarak hiçbir istisnai savaş tedbirine tabi tutulmadıklarından Karma Hakem Mahkemesinin bu işe bakmaya yetkili olmadığına karar vermişlerdi. $^{71}$

Karma Hakem Mahkemelerinin yetkisizlik kararını açıklamasını Cumhuriyet gazetesi aceleci bulmuştu; nitekim bir iki gün önce Türk Umumi Ajanlığı, Bakanlar Kurulu Kararı ile mahkemeye bir nota göndermiş ve bu notada Türk Hükümeti tarafından gönderilecek Abdülhamit'in mirasçılarının emlakine ait listenin gelmesinden önce bir karar verilmemesini talep etmişti. Mahkeme bu notaya rağmen ve hangi maksatla olduğu anlaşılmaksızın beklemeden karar vermişti.

Cumhuriyet gazetesinde, Abdülhamit'in varisleri tarafindan geri verilmesi talep edilen taşınır ve taşınmaz mallar şahsi ve özel oldukları için ve bunların sahiplerine iadesini içeren hükümler Lozan'da kabul edilmiş oldukları için Türk Hükümetinin kendisine verilmiş olan bu taahhüdün yerine getirilmesini siyasi yollardan İngiliz ve İtalyan hükümetlerinden talep edeceği yer almıştı. Diğer devletler Türkiye'yi Lozan'1 uygulamaya davet ederken Türkiye'nin de aynı şeyi talep etmesi doğaldı. ${ }^{72}$

Karma Hakem Mahkemelerinden istedikleri sonuç çıkmasa da II.Abdülhamit'in mirasçıları pes etmediler. Filistin'de Gazze yakınlarındaki arazi parçası için dava açıldı. İngiltere ve Avrupa'daki en yüksek hukukçular bu işe memur edildi. On bir yıl süren dava 1945 sonunda mirasçılar için olumsuz sonuçlandı. Bundan sonra yurt dışında yeni bir teşebbüs olmadı. ${ }^{73}$

Volume 12

Issue 2

A Tribute

to Assoc.

Prof. Dr.

İlknur

Mangir

Karagöz,

Türkiye'nin Lozan'da 1908 ve 1909 iradelerinin hükümsüz olduğunu ileri sürmesi ve Türkİtalyan ve Türk-İngiliz Karma Hakem Mahkemelerine Türk ajanlığı tarafından da iradelerin hükümsüzlügü yönünde yazılar gönderilmesi mirasçıların ileride Türkiye dâhilindeki miras istemleri için dayanak oluşturmuştu. Türk Hükümeti'nin II.Abdülhamit'in yurt dışındaki mirasının varislere geçişini desteklemesi yurt içindeki mirası da kabul etmesi gerektiği yorumlarına neden olmuştur. Varislerin yurt içindeki talepleri ile yine Günzberg'in meşgul olduğu görülmüştür. ${ }^{74}$ Konumuzun dışında kalan mirasçıların yurt içindeki talepleri ise çeşitli dönemlerde yapılan düzenlemeler ile engellenmiştir. ${ }^{75}$

\section{Karma Hakem Mahkemelerinin Tasfiyesi}

Mayıs 1931 tarihi itibariyle Karma Hakem Mahkemelerindeki davalar azalmaya, hakem mahkemeleri dağıtılmaya başlamıştı. Bu nedenle kadro düzenlemelerine ihtiyaç duyulmuş ve hakemlerden Memduh Bey ile Mehmet Ali Beyler kadro harici bırakılmışlardır; ancak Mehmet Ali Bey sonradan görevine iade edilmişti. Türk-İtalyan ve Türk-İngiliz mahkemelerinden kadro

\footnotetext{
71 “Abdul Hamid's Heirs”, “Two Adverse Decisions”, The Times, 17 Aralık 1930; “Abdülhamit Veresesi Davas1 Dün Bitti”, Cumhuriyet, 17 Kanunuevvel 1930.

72 “Abdülhamit Veresesi Davası Dün Bitti”, Cumhuriyet, 17 Kanunuevvel 1930.

${ }^{73}$ Şensözen, age, s. 98-100; Koçak, age, s. 107- 113, 127.

${ }^{74}$ Koçak, age, s. 36-40.

75 Bkz. 1949 tarihli pasaport kanununa bazı maddeler eklenmesine dair kanun için bkz. Şenözen, s.95; Koçak, s. 6970, 90. Resmi Gazete, 25 Nisan 1949, S. 7129. 1949 y1lında yapılan 3 Mart 1924 tarihli kanunun 8.maddesinin yeniden yorumlanması yönündeki değişiklik için bkz. Şensözen, age, s. 94. Resmi Gazete, 7 Mayıs 1949, S. 7201. 1952'de Demokrat Parti döneminde kabul edilen Hilâfetin İlgasına ve Hanedanı Osmaninin Türkiye Cumhuriyeti memaliki haricine çıkarılmasına dair olan 3 Mart 1924 tarihli kanuna Ek Kanun Tasarısı için bkz. Koçak, age, s. 103-105; Resmi Gazete, 23 Haziran 1952, S. 8142.
} 
harici kalan Memduh Beyin yerine yalnız Türk-İtalyan mahkemesi hakemliğine Türk-Belçika mahkemesi hakemi müderris Cemil Bey tayin edilmiştir. ${ }^{76}$

Lozan Antlaşması uyarınca kurulan Türk-İngiliz Karma Hakem Mahkemesi altı yıllık çalışmasının ardından Nisan 1932'de çalışmasını sona erdirdi. Mahkeme başkanı altı yıl boyunca M. Kai Hammerich olmuştu. Hammerich Kopenhag temyiz mahkemesinin hâkimi idi. Mahkemedeki İngiliz üye W.H.Hill olmuştu. Hill, Kahire'deki Mısır Temyiz Mahkemesinin hâkimi idi. Mahkemenin Türk üyesi Hukuk Fakültesi Müdürü Cemil Beydi. R.C. Owen-Wells İngiliz ve Emin Ali Bey Türk ajanı idi.

Alt1 yıl boyunca mahkemede 558 dava görülmüştü. The Times, İngiliz Hükümetine karş1 yapılanların hiçbirinin başarılı olamadığını belirtmişti. The Times bu davalar içerisinde en önemlilerinin Eski Mısır Hidivi Abbas Hilmi Paşa'nın açtığı 2.000.000 liralık dava; Sultan II. Abdülhamid'in mirasçılarının Irak, Filistin ve Kıbrıs'taki mülklerinin düzenlenmesi için açtı̆̆ 1 dava ve Malta sürgünleri davası olduğunu yazmaktaydı. 80 İngiliz davacı savaşta ele geçen mülklerin iadesi ve bunlara bağlı borçların ödenmesi için Türk Hükümetine ve Türk unsurlarına açtığı davayı kazanmıştı. ${ }^{77}$

Nisan 1932'de Türk-İngiliz mahkemesinin elinde 40 kadar dava kalmıştı. Bunlar üzerinde incelemeler son bolunca kararını bildirecek ve mahkeme görevini tamamlayacaktı. İngiliz sefaretinde de görevini tamamlamak üzere olan mahkeme şerefine öğlen ziyafeti verilmişti. ${ }^{78}$

Karma-Hakem mahkemeleri ile ilgili genel bir değerlendirme yapmak gerekirse, mahkemelerin oluşumundan itibaren mahkemelerde 13.042 dava açıldığı görülür. Bunlardan 111'i Türk-Romen mahkemesinde açılmıştı. 24'ü neticelenmiş, 87 tanesi siyasi yollarla halledilmek üzere kalmıştı.

Türk-İngiliz mahkemesinde 558; Türk-İtalyan Mahkemesinde 64; Türk-Belçika mahkemesinde 43 davanın hepsi bitmiş, hükümler verilmiş, mahkemeler faaliyetlerini tamamlamıştı.

Mart 1934 itibariyle Türk-Fransız mahkemesindeki 150 davadan 107'sinin hükmü verilmiş, incelenmekte olan 43 dava kalmıştı. Türk-Yunan mahkemesindeki 12.116 davadan 11.021'i sonuçlanmış, elde 1.095 tane sava kalmıştı.

Görevlerini tamamlayan mahkemelerden Romen mahkemesi üç sene iki ay; İngiliz mahkemesi altı sene; İtalyan mahkemesi üç sene on bir ay; Belçika mahkemesi altı sene on bir ay çalışmıştır. İlk işe başlayan Fransız mahkemesidir. 3 Kanunuevvel 1925 'ten beri faaliyet göstermektedir. ${ }^{79}$ En son tasfiye olan da Türk-Fransız Karma Hakem Mahkemesi olmuş, Mayıs 1936'da tasfiye edilmiş, Türk delegeleri asliye ve ticaret mahkemesi azalıklarına tayin olmuştur. Bu şekilde Lozan Antlaşmasının bu faslı da kapanmıştır. ${ }^{80}$

Bununla birlikte Karma Mahkemelerinin tamamen tarihe karışmasının zaman aldığı 1942 yılında çıkartılan Bakanlar Kurulu kararından anlaşılmaktadır. Türk-İngiliz Karma Hakem Mahkemesinden çıkıp haklarında infaz kararı verilmiş olduğu halde kısmen veya tamamen infaz edilmemiş olanlar ile ilgililerin takip etmemesi dolayısıyla hiçbir incelemeye tabi

\footnotetext{
76 "Hakem Mahkemeleri”, “Davalar Azaldı Tensikat Yapılıyor”, Cumhuriyet, 3 Mayıs 1931.

77 "End of the Anglo- Turkish Tribunal", "Record for Six Years", The Times, 23 Nisan 1932.

78 “Türk-İngiliz Mahkemesi”, "Muhtelit Mahkeme İşini Bitirdi Dağıllyor”, Cumhuriyet, 22 Nisan 1932

79 "Muhtelit Mahkemelerde", "Biten ve Kalan Davalar Ne Kadardır", Cumhuriyet, 22 Mart 1934.

80 "Muhtelit Mahkeme", "İşleri Bittiğinden Muahedenin Bu Faslı da Kapandı", Cumhuriyet, 10 Mayıs 1936. Bu mahkemede sadece bir dava halledilemeden kalmıştı o da Perier Bankasının Türkiye'ye açtığı 1,500,000'luk alacak davasıydı. Mahkeme davayı hakeme vererek görevine nihayet vermişti. Bkz. "Perier Bankasına Olan Borç", Cumhuriyet, 28 Birincikanun 1936. 
tutulmamış olanları kapsamak üzere para, menkul ve gayrimenkul olan tüm ilâmlardan ortaya çıkan İngiliz alacaklıların İngiliz Hükümetince hem kendi adına hem ilâm sahipleri olan alacaklılar, davayı kazanmış olanlar adına bu ilâmdan doğan tüm taleplerden dolayı, Türk Hükümeti borçtan kurtulmak şartıyla on sene ve on eşit taksitte faizsiz ve toplam 107,100 Türk lirası ödenmek suretiyle toptan tasfiyesi konusunda İngiliz Hükümeti ile mektup teatisi ve bir anlaşma yapılması için Dışişleri Bakanlığına yetki verilmesi, Dışişleri Bakanlığının 15 Temmuz 1942 tarihli teklifi ve Maliye Bakanlığının 15 Eylül 1942 tarihli mütalaası üzerine Bakanlar Kurulunca 26 Ekim 1942 tarihinde kabul olunmuştur. Kararname Cumhurbaşkanı İsmet İnönü'nün imzasını taşımaktadır. ${ }^{81}$

Akçam ve Kurt Türk-İngiliz Karma Hakem Mahkemesinin görevini tamamlayamadığını, mahkemelerin ellerindeki pek çok dosyaya bakamadığını bunun üzerine konunun iki devlet arasında mektup teatisi yoluyla halledilmeye çalışıldığını belirtir. Akçam ve Kurt anlaşma tarihini 23 Mart 1944 olarak belirtir. Buna göre, Türkiye, açık kalan tüm dosyaları kapatmak için belirtilen miktarı ödemeyi kabul etmiştir. Türk Hükümeti tarafından verilen mektupta, bu miktarın ödenmesinin Türk Hükumetini İngiliz Hükümeti ve vatandaşlarının Türk-İngiliz Karma Hakem Mahkemesinin kararlarından doğan yükümlülüklerden muaf tutacağı belirtilmektedir. İngiliz Büyükelçiliğinin cevabi notasında daha önce sözlü olarak varılan bu mutabakatın kendilerince de onaylandığ 1 yer almaktadır. ${ }^{82}$

\section{Sonuç}

Lozan Antlaşması'nın ilgili maddeleri uyarınca kurulan altı adet Karma Hakem Mahkemesi, her biri farklı tarihlerde kurulmak ve kapatılmak üzere, 1920'lerin ortalarından 1930'ların ortalarına kadar çeşitli dönemlerde faaliyet göstermiştir. Osmanlı Devleti'nin yıkılmasının ardından şekillenen yeni süreçte Türk vatandaşları ile müttefik devletlerarasındaki ve müttefik

Volume 12

Issue 2

A Tribute

to Assoc.

Prof. Dr.

İlknur

Mangir

Karagöz,

April

2020 devlet vatandaşları ile, yabancı statüdeki şirketler de dâhil, Türk devleti arasındaki anlaşmazlıkları çözümleme gayesi ile kurulan Karma Hakem Mahkemeleri ile ilgili ayrıntılı bir çalışma bulunmamaktadır. Kuşkusuz ki Mahkemelerde binlerce davanın görülmesi Karma Hakem Mahkemeleri ile ilgili derinlemesine bir incelemeyi gerektirmektedir.

Dönemin gazetelerinde mahkemelerde görülen davalara ilişkin ayrıntılı bilgilere rastlamak mümkündür. Mahkemelerin bütçelerinden, mahkemelere tayin edilen hakemlere kadar detaylı haberler yayınlanmıştır. Türk-İngiliz Karma Hakem Mahkemesinde görülen ele aldığımız ilk iki dava, Malta sürgünleri davası ve Abbas Hilmi Paşa davası, 1927 yılında, az çok aynı dönemde görülmeye başlamış ve beraberce aynı oturumda sonuçlanmıştır. Üçüncü dava olan II.Abdülhamit'in mirasçılarının açtı̆̆ dava ise 1930 yılında görülmüştür. Basın ve kamuoyunda oldukça ses getiren bu üç davanın da akıbeti aynı olmuş ve Mahkemece yetkisizlik kararı verilmiştir. Yetkisizlik kararı Türk basınında eleştirilere konu olurken İngiliz basını mahkemeyi haklı bulmuştur. Biz de bu nedenle her üç davanın sonuçlanmasını aynı başlık altında inceledik.

Her üç davada da davacıları dönemin en önde gelen Türk hukukçularının savunduğunu tespit ettik. Bu durum Türk tarafının Mahkeme sürecine verdiği değeri göstermesi bakımından önemlidir. Bu üç davanın bir ortak özelliği ise ekonomik yönünün ötesinde siyasi boyuta sahip olmalarıdır. Bu nedenle TBMM'de davaların gündeme geldiği görülmüş, Bakanlar Kurulundan davacıların haklarının korunması adına adımlar atılması gerektiği yönünde kararlar çıkmıştır. Dışişleri Bakanından Başbakana Türk devlet adamları her üç davada da davacıları desteklemiştir. Türk Devleti'nin Abbas Hilmi Paşa davasında eski Hıdivin Türk vatandaş1

\footnotetext{
${ }^{81}$ BCA. Başbakanlık Kararlar Daire Başkanlı̆̆ (1928-), 30.18.1.2/100.90.16., 26.10.1942.

${ }^{82}$ Akçam- Kurt, age, s. 136, 173.
} 
olduğunu kanıtlama adına uğraşması ve II.Abdülhamit'in mirasçılarının Türkiye dışındaki miras taleplerini desteklemeleri ilgi çekicidir.

\section{Kaynakça}

\section{1-Arşiv Belgeleri}

A) Devlet Arşivleri Başkanlığı Osmanlı Arşivi (BOA)

Hariciye Nezareti İstanbul Murahhaslığı (HR. İM), 219/47; 246,163.

B) Devlet Arşivleri Başkanlığı Cumhuriyet Arşivi (BCA)

Başbakanlık Kararlar Daire Başkanlığı(1920-1928), 30.18.1.1./ 21.72.13; 30.18.1.1./13.27.11.

Başbakanlık Kararlar Daire Başkanlığı (1928-), 30.18.1.2/100.90.16.

Başbakanlık Muamelat Genel Müdürlüğü, 30.10.0.0./17.99.3

\section{2- Resmi Yayınlar}

Türkiye Büyük Millet Meclisi Tutanak Dergisi, Dönem: VIII, C. 22, Toplantı: 4, Yirminci Birleşim, 21.12.1949.

Resmi Gazete

\section{3- Süreli Yayınlar}

Cumhuriyet

Hakimiyet-i Milliye

Milliyet

The Times

Vakit

\section{3- Araştırma-İnceleme Eserleri}

AKÇAM, Taner- Ümit Kurt, Kanunların Ruhu, İletişim Yayınları, İstanbul, 2012.

DOĞAN, Galip, “Ord.Prof. Tahir Taner (1883-1956)”, Terazi Hukuk Dergisi, C.2, S.16, 2007, s. $183-185$.

KOÇAK, Cemil, II. Abdülhamid'in Mirası, ARBA Yayınları, İstanbul, 1990.

KÜÇÜK, Cevdet, “Abdülhamid II”, TDV İslam Ansiklopedisi, C.1, İstanbul, 1988, s. 216- 224.

MCKALE, Donald M., "Influence without Power: the Last Khedive of Egypt and the Great Powers, 1914-18”, Middle Eastern Studies, C. 33, S. 1, 1997, s. 20-39.

MERAY, Seha, Lozan Barış Konferansı Tutanaklar-Belgeler, Konferansda Imzalanan Senetler (30 Ocak ve 24 Temmuz 1923), İkinci Takım, C.II, Yapı Kredi Yayınları, İstanbul, 2001. 
MERAY, Seha, Lozan Barış Konferansı Tutanaklar- Belgeler, Üçüncü Komisyonun Tutanaklart ile Raporlart (Iktisat ve Maliye Sorunlart), Birinci Takım, C.III, YKY İstanbul, 1993.

ŞAHIN, İlhan, “Abbas Hilmi II” TDV İslam Ansiklopedisi, C.1, İstanbul, 1988, s. 25-26.

ŞENSÖZEN, Vasfi, Osmanoğulları'nın Varlıkları ve II. Abdülhamid'in Emlaki, TTK Basımevi, Ankara, 1982.

ŞİMŞiR, Bilal, Lozan Telgrafları I (1922-1923), TTK Basımevi, Ankara, 1990,

ŞİMŞiR, Bilal, Malta Sürgünleri, Milliyet Yayınları, Tarih Dizisi, İstanbul, 1976.

TBMM Albümü (1920-2010), Haz: Sema Yıldırım-Behçet Kemal Zeynel, TBMM Basın ve Halkla İlişkiler Müdürlüğü Yayınları No: 1, Ankara, 2010

TOKER, Yalçın, Malta Sürgünleri’nden Portreler, Toker Yayınları, İstanbul, 2006.

ULUĞBAY, Hikmet, Imparatorluk'tan Cumhuriyet'e Petropolitik, De Ki Basım Yyaim Ltd.Şti., Ankara, 2008.

YALMAN, Ahmet Emin, Yakın Tarihte Gördüklerim ve Geçirdiklerim, Yay.Haz. Erol Sadi Erdinç, C. I, Pera Turizm ve Ticaret A.Ş., İstanbul, 1997.

Volume 12 
Lozan Antlaşması Sonrası Kurulan Karma Hakem Mahkemeleri...

EK 1- Malta sürgünlerinin açtıkları dava ile ilgili "Malta'ya Teb'îd Edilenler Haklarını İstiyor" başlı̆̆ 1 ile 10 Haziran 1927'de Milliyet gazetesinde yayınlanan haber

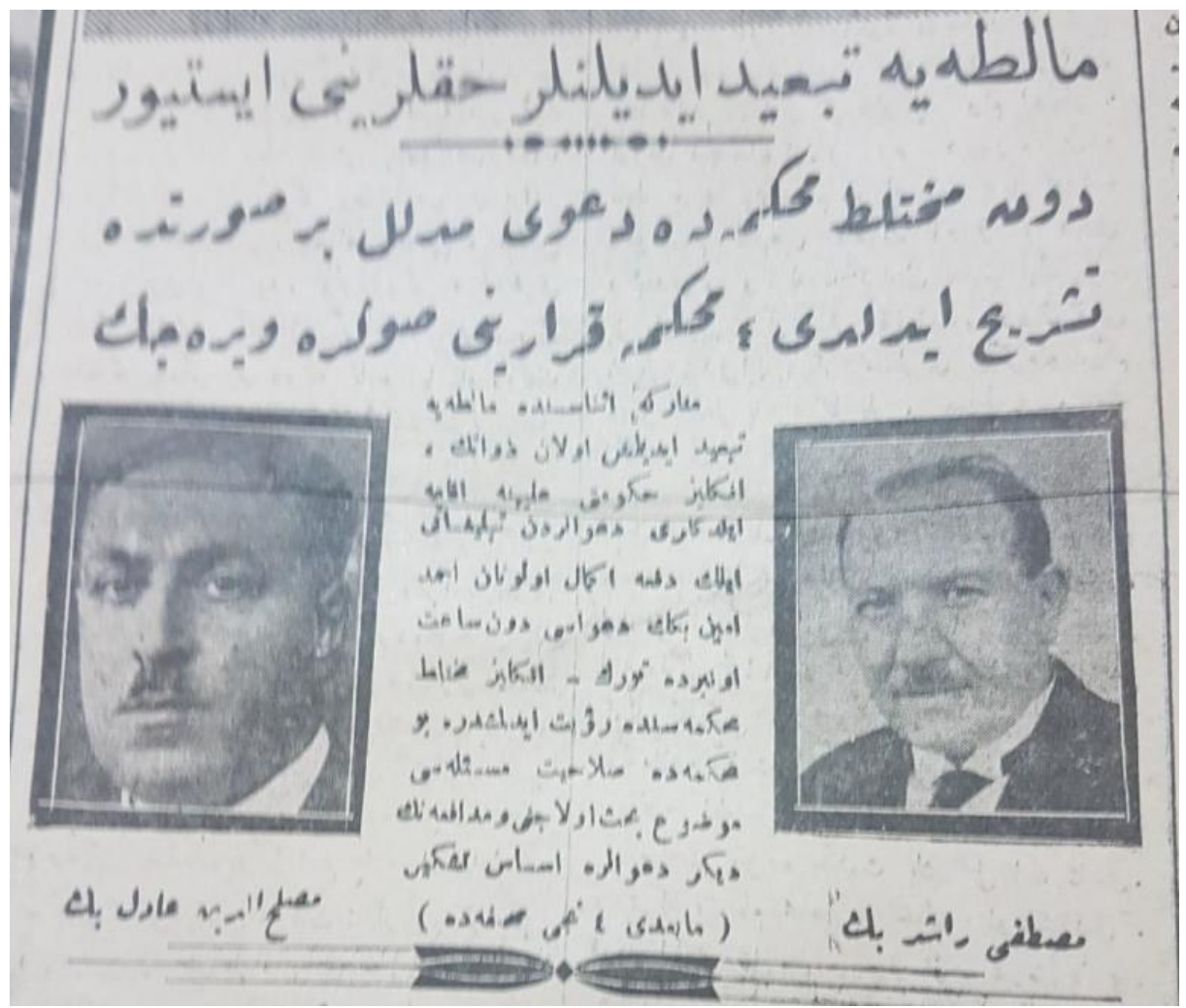




\section{Irmak Karabulut}

EK-2: "Muhtelit Mahkemelerde Reviyyete Devam Edilen Dava", "Abbas Hilmi Paşanın Müdafaa Vekilleri Paşanın Türk Tabiiyetinde Olduğunu ve Muhtelit Mahkemenin Bu Davayı Reviyyet Edebileceğini İspat Ettiler”, başlığı ile Vakit, gazetesinde 2 Mayıs 1927 tarihinde yayınlanan haber

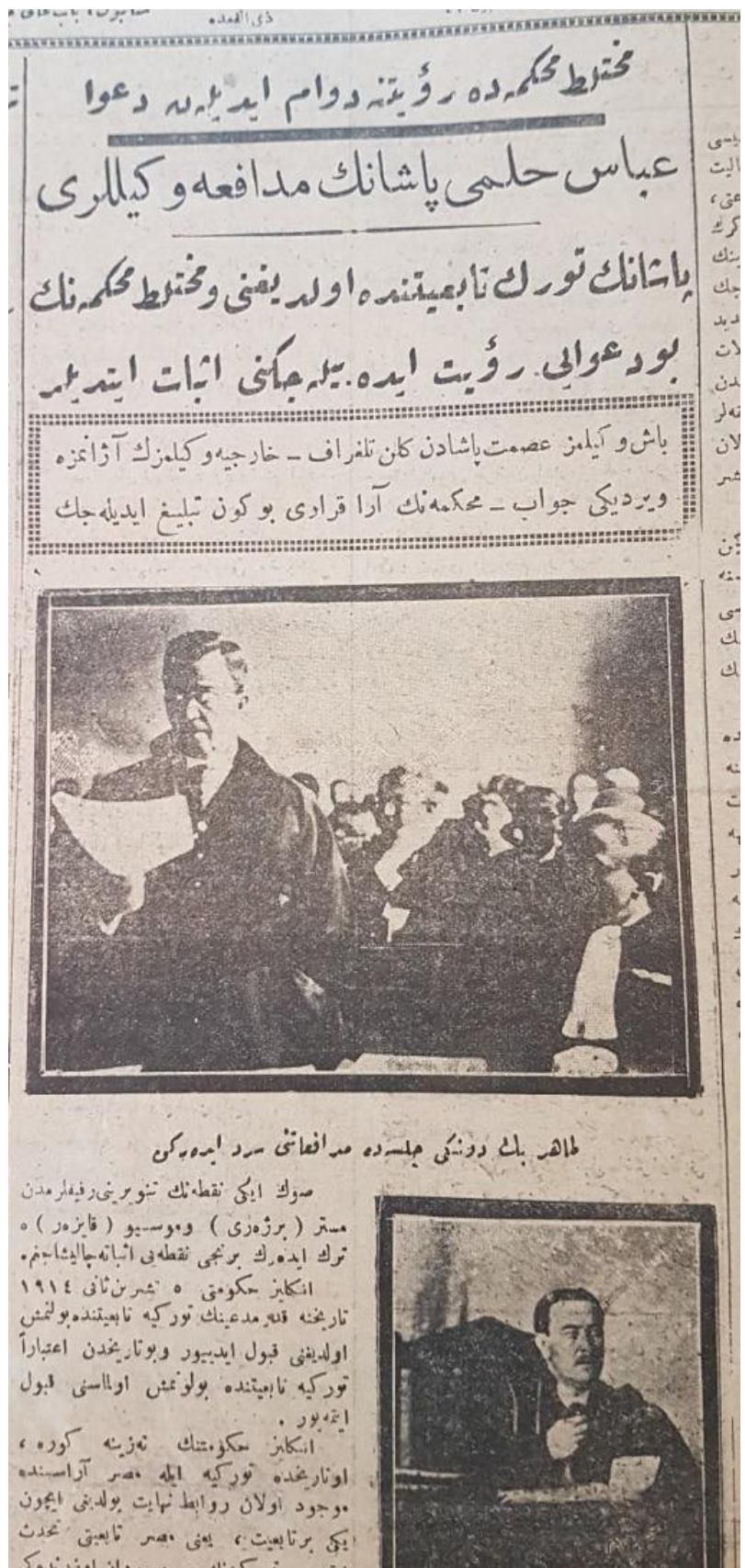


EK-3: 23 Kasım 1930 tarihli Cumhuriyet gazetesinde yayınlanan haber

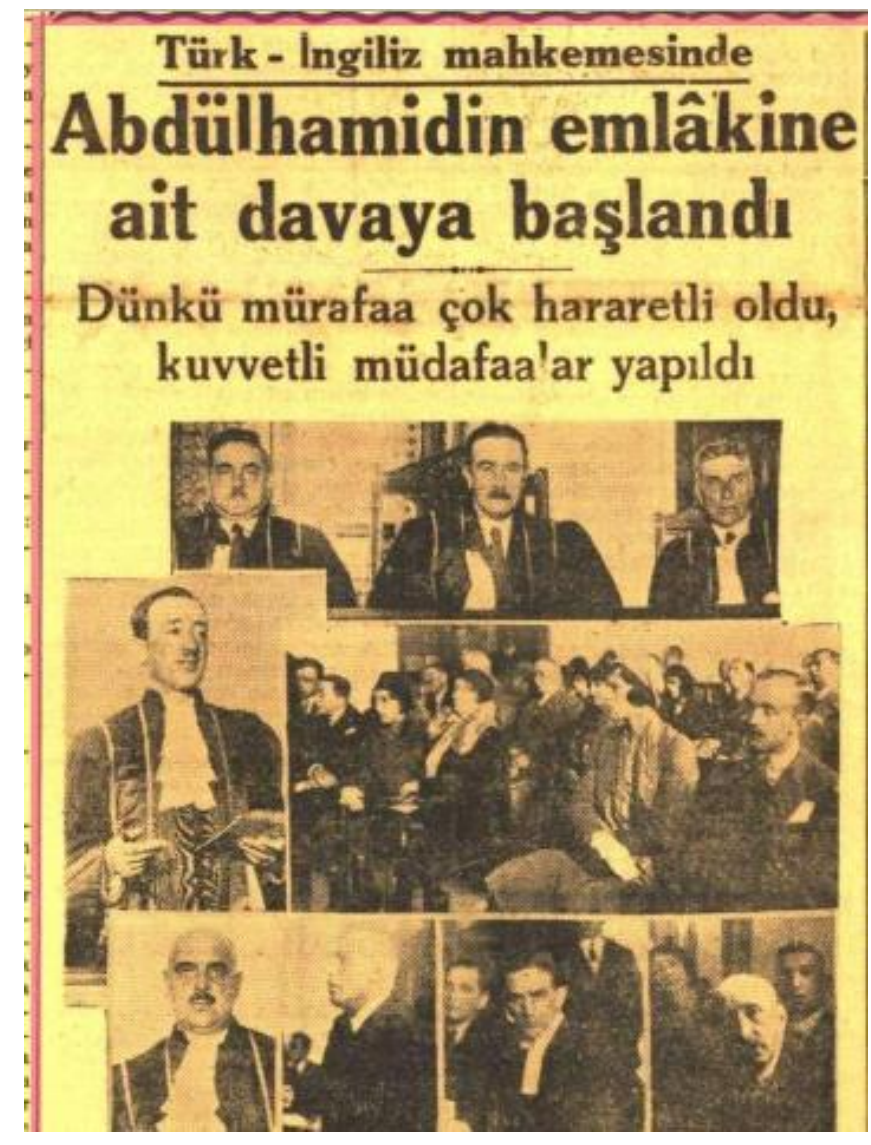




\section{Irmak Karabulut}

EK-4: Türk- İngiliz Karma Hakem Mahkemelerinin çalışmalarını tamamladıkları hakkında 23

Nisan 1932 tarihli The Times gazetesinde yer alan haber

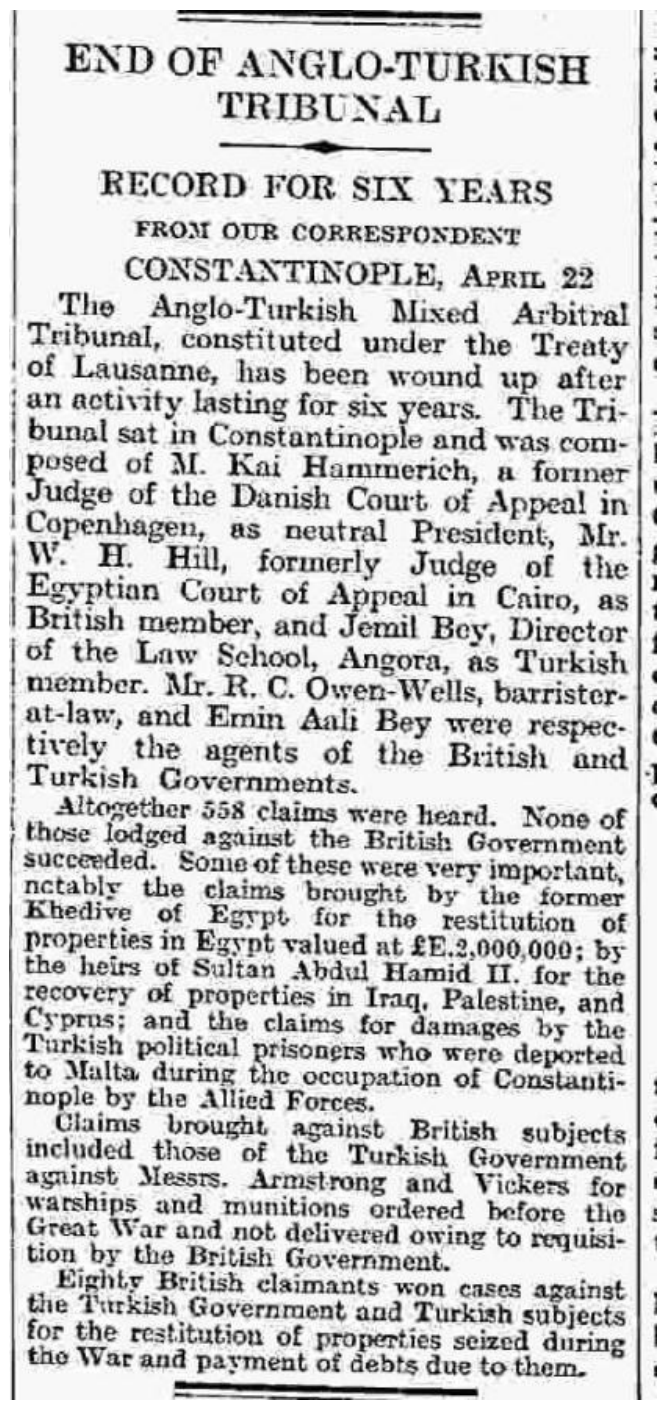

